\title{
Somogy megye molylepke faunája (Lepidoptera: Microlepidoptera)*
}

\author{
FAZEKAS IMRE
}

\begin{abstract}
FAzEKAS I.: Microlepidoptera fauna of Somogy county (SW Hungary) (Lepidoptera: Microlepidoptera)* Abstract: The author summarizes Somogy county's Microlepidoptera fauna for first time. He shows that 971 species were found in the county. 6 species and subspecies are endemic in the Carpathian Basin. The locus typicus of some sepecies and subspecies is here: Rhigognostis korácsi (Gozmány, 1952), Pyroderces klimeschi Rebel, 1938, Sophronia ascalis (Gozmány, 1951), Merrifieldia malacodactyla transdanubinus (Fazekas, 1986).
\end{abstract}

\section{- Bevezetés}

A Praeillyricum faunajárásba tartozó Somogy megye microlepidoptera faunájának megismerés-történetét négy, egymáshoz szervesen nem kapcsolódó korszakra lehet osztani. Az egyes kutatástörténeti intervallumokban a faunafeltárás csak ad hoc jellegú volt, s egy-egy kevésbé ismert élôhely faunájára irányult (pl. Kis-Balaton), vagy döntóen a megyeszékhely környékére korlátozódott (leg. Nattán). Más esetekben a tervszerúnek induló gyújtéseket csupán 1-2, többnyire fajlistákra korlátozott rövidebb közlemények zárták le (pl. barcsi borókás). A megye teljes egészét átfogó vizsgálat még nem indult el.

Megismerés-történeti szempontból a XIX. században somogyi microlepidoptera kutatásról még nem beszélhetünk. Ebben a korszakban Magyarországon csak Uhrik Nándor orvos és Pável János, a Nemzeti Múzeum preparátora foglalkozott rendszeresen molylepkékkel. Pável a Fauna Regni Hungariae microlepidoptera fejezetének összeállításánál a bécsi Otto Bohatsch-ot is felkereste, akivel „... a bécsi udv. múzeumban a hazai microlepidopterákat összeírta." Ekkor a történelmi Magyarország tèrületéról 1246 molylepke fajt ismertek. A mai határokon belül ez a fajszám napjainkra 2070 fölé emelkedett. ABAFIAIGNER et al. (1896) a magyarországi microlepidoptera kutatás állapotát a XIX. század végén így jellemezték: „...nálunk a régi idók óta voltak ugyan kedvelôi és müvelöi a lepidopterologiának, de alig akadtak olyanok, akik microlepidopterákkal is behatóan foglalkoztak volna." A faunisztikai célú gyújtések mellett jelentôs fejlődésnek indult az úgynevezett kártevő molylepkefajok kutatása is, amely elsősorban Jablonowski József nevéhez kötớdik (SzILÁDY, 1903). ABAFI-AIGNER et al. (1896) faunakatalógusa alapján a megyét „terra incognitana"-nak tekinthetjük, hiszen Somogyból egyetlen microlepidoptera adatot sem tettek közzé. A Fauna Regni Hungariae csupán négy somogyi lelóhelyről számol be (Barcs, Drávafok, Somogyszob, Zákány), amelyek kizárólag a nagylepkékre vonatkoznak.

\footnotetext{
* Microlepidoptera Pannoniae meridionalis II.
} 
A fauna megismerésének második korszaka fóleg a két világháború közötti évtizedekre esik, amikor több magyar, osztrák és német gyưjtố kereste fel, elsősorban a Kis-Balaton területét. A gyújtött anyag részben a Magyar Természettudományi Múzeumba, másrészt a bécsi Naturhistorisches Museum-ba vagy a müncheni Zoologische Staatssammlung-ba került, de kisebb sorozatok privát collectiokban is megtalálhatók (in coll. Klimesch, A-Linz). Ebból az idószakból ki kell emelnünk Hans Rebel-t (1861-1940), a nagyszerú bécsi lepidopterológiai iskola (Ochsenheimer, Treitschke, Lederer, Rogenhofer) egyik kiemelkedô alakját, a Naturhistorisches Hofmuseum főigazgatóját, aki élénk érdeklődést mutatott a somogyi molylepkék iránt. Többek között az ő nevéhez füződik a Pyroderces klimeschi Rebel, 1938 (Fam. Cosmopterigidae) faj leírása. A taxont a közelmúltban elhúnyt linzi microlepidoptera specialistáról, Josef Klimesch-ról (1902-1997) nevezte el. A korabeli irodalmakban (pl. BALOGH, 1939) sajnos csak igen ritkán találkozhatunk somogyi molylepke fajokkal. Ez alól kivétel SzENT-IVÁNY \& UHRIK-MÉSzÁros (1942) Pyraloidea faunakatalógusa, amelyben az előzô publikációkhoz képest először kapunk képet egy családsorozat somogyi fajairól. Ebben az idôszakban kezdett el dolgozni a II. világháborúban elhunyt Ház Antal kaposvári gyúitő. A pécsi Janus Pannonius Múzeumban ôrzött Nattán-gyúitemény etikettjei szerint Ház a '30-as években kezdte el molylepke gyújtéseit. Kaposváron ebben a korban az ország egyik legaktívabb lepidopterológiai decentruma kezdett kialakulni, amelyet olyan nevek fémjeleztek, mint Karvajszky István, Hámory Aladár, Ház Antal, Pazsiczky Sándor és Nattán Miklós. A kaposvári lepkészek között igazi microlepidopterológust nem találunk. Gyúitéseik főleg a nagylepkékre irányultak, a molylepkék csupán alkalmilag keltették fel figyelmüket.

A Somogy megyei microlepidoptera kutatás Nattán Miklós (1910-1970) fellépésével harmadik korszakába lépett, amely a '40-es években kezdódött és haláláig tartott. Munkássága nyomán a megye az ország egyik legjobban kutatott területei közé emelkedett. Gyújteményében mintegy 750-770 fajt találunk (in coll. JPM Pécs). Sajnos Nattán Miklós gyújtési eredményeit kortársaihoz hasonlóan (pl. Reskovits Miklós, Eger) nem publikálta. Ennek ellenére faunisztikai eredményei beépültek az ' 50 -es években megindult Fauna Hungariae füzetsorozatba (vö.GOZMÁNY \& SzŐCS, 1955-1965). Nattán Miklós odaadó munkássága nélkül ma a Somogy megyei microlepidoptera fauna ismeretéról nem beszélhetnénk. Sajnálatos módon gyüitései főleg Kaposvár környékére korlátozódtak, $s$ a lelóhelycédulák tanulsága szerint a munka nem volt folyamatos, így az általánosan elterjedt, euriotopikus fajokat is csak időközönként gyúitötte (pl. Cydia pomonella L., Crambus perlellus Sc., Endotricha flammealis D. \& Sch., Nomophila noctuella D. \& Sch. stb.), így a gyújtemény populációdinamikai vizsgálatokra nem alkalmas. Az esetleges extinkciós folyamatokat ma csak részben tudjuk nyomon követni.

A Nattán-gyúitemény adatainak részbeni publikálása SzABÓKY (1983a) nevéhez fúződik. Bár a szerzô tanulmányában „teljes” revizióról beszélt, a valóságban ez nem következett be. Ezekre a reviziós anomáliákra magam már egy korábbi munkámban is rámutattam (FAZEKAS, 1986). A Nattán-gyújtemény bemutatásának egyik legnagyobb problémája az volt, hogy egy olyan elavult, s már sehol sem használatos nevezéktant, valamint rendszertant alkalmazott, amely a gyakorlati faunisztikában csak teljes átdolgozás után vált áttekintehetővé, avval a megjegyzéssel, hogy több faj és fajcsoport identifikációja további taxonómiai munkát igényel. Az un. Nattán-korszakhoz kötődik a Magyar Természettudományi Mưzeum kis-balatoni vizsgálata is, amelyben GOZMANY (1956b) a microlepidopterák társulási viszonyait elemezte. 
Nattán Miklós 1970. évi tragikus halála után (GozMÁNY, 1971) Somogy megye feltárásában több éves szünet állt be. Bár ezután is találunk szórványos molylepke adatokat a magyar irodalomban (pl. Szốcs, 1973), a somogyi microlepidoptera kutatások negyedik korszaka csak a '80-as években a dél-dunántúli régió (FAZEKAS, 1980, 1988, 1989) és a Barcsi Borókás TK vizsgálatával indult el (FAZEKAS, 1981; SZABÓKY, 1983b, 1985). Az ezt követő években sorozatban jelentek meg azok a faunisztikai, taxonómiai és állatföldrajzi tanulmányok, amelyek a legújabb európai, valamint palearktikus vizsgálati eredményeket is figyelembe véve több új adattal gazdagították a megye microlepidoptera faunájának ismeretét (FAZEKAS, 1991, 1992a, 1992b, 1994abc, 1995abcd, 1998, 2000ab; LASTUVKA, 1990; NAUMAN et al. 1999). A rendelkezésünkre álló vizsgálatok alapján Somogy megyéből csak a következő taxonokról vannak megbízható taxonómiai és ökofaunisztikai feldolgozások: Zygaenidae (FAZEKAS, 1980, 1996, 1998, 2000b), Crambinae et Schoenobinae (FAzekas, 1986, 1989, 1994b), Pterophoridae (FAzeKas, 1988, 1992a, 2000a), Cochylini (FAZEKAS, 1994c), Epermeniidae (GAEDIKE, 1966), Sesiidae (LASTUVKA, 1990). Az elóbbiek csupán 7 családot érintettek (Tortricidae partim). 50 család kutatását az alapoknál kell elkezdeni, s a vizsgálatokat a megye egész területére ki kell terjeszteni. A megyei múzeum természettudományi osztályán lévő 7 doboznyi gyújteményt tovább kell fejleszteni.

Jelen tanulmányom az elsố kísérlet arra, hogy az eddigi publikációs és gyúiteményi adatokat összesítse, s kiindulási alapot adjon a következó évek taxonómiai, ökofaunisztikai, állatföldrajzi és természetvédelmi kutatásaihoz. Több mint száz év eredményeinek összegyứjtése mindig nehéz feladat. Bizonyára több adat is elkerülte a figyelmemet, $s$ ezek pótlása a következő évek feladata lesz. Mint minden kvalitatív faunisztikai alapvetés, ez a munka is egy korábbi időszak lezárására törekedett, abban a reményben, hogy újabb kutatások elött nyílik lehetôség.

A fajok nevezéktanában, a taxonok rendszertanában folyamatos változások vannak, $s$ ez különösen érvényes a microlepidopterákra. Az áttekinthetőség, a fajlista könyebb kezelhetősége szempontjából a RAzOWSKY \& KARSHOLT (1996) által szerkesztett „The Lepidoptera of Europe" címú alapmunkát vettem figyelembe. Néhány általam részletesebben vizsgált családnál (pl. Gelechiidae, Zygaenidae, Pterophoridae, Pyralidae, Crambidae), ahol azt az újabb nevezéktani, taxonómiai és biogeográfiai okok idokolttá tették, módosításokat tettem (vö. ARENBERGER, 1995; FAZEKAS, 1995e, 1996, 1998, 2000ab; Gielis, 1996; Huemer \& Karsholt, 1999; NaumanN et al. 1999; Efetov \& TARMAnN, 1999).

A szinoním neveket csak akkor adom meg, ha az újabb nevek alapján, a magyar irodalomban a kérdéses taxont problematikus volna azonosítani. Ha a fajok neve után jelzetet találunk (pl. [1.]*), akkor a névjegyzéket követő „Jegyzetek" címú fejezetben rövid magyarázatot adok. 


\section{A fajok névjegyzéke}

\section{Micropterigidae}

Micropterix aruncella (Scopoli, 1763)

M. calthella (Linnaeus, 1761)

M. myrtetella Zeller, 1850

M. tunbergella (Fabricius, 1787)

\section{Eriocraniidae}

Eriocrania subpupurella (Haworth, 1828)

E. sparrmannella (Bosc, 1791)

\section{Hepialidae}

Triodia sylvina (Linnaeus, 176I)

Hepialus humuli (Linnaeus, 1758)

Nepticulidae

Stigmella tiliae (Frey, 1856)

Ectoedemia rubirora (Wocke, I860)

\section{Opostegidae}

Opostege spatulella Herrich-Schäffer, I 855

O. salicella (Treitschke, I833)

Pseudoopostega crepusculella (Zeller,1839)

\section{Heliozelidae}

Antispila metalella (Denis \& Schiffermüller, 1775)

A. treitschkiella (Fischer v. Röslerstamm, 1843)

\section{Adelidae}

Nemaphora degeerella (Linnaeus, 1758)

$N$ raddella (Hübner, 1793)

N. metallica (Poda, 1761)

N. auricellus (Ragonot, 1874)

N. fasciella (Fabricius, 1775)

N. minimella (Denis \& Schiffermüller, 1775)

Adela violella (Denis \& Schiffermüller, 1775)

A. reaumurella (Linnaeus, 1758)

A. croesella (Scopoli, 1763)

Cauchas rufifrontella (Treitschke, 1833)

C. fibulella (Denis \& Schiffermüller, 1775)

C. leucocerella (Scopoli, 1763)

C. rufimitrella (Scopoli, 1763)

Nematopogon adansoniella (Villers, 1789)

N. metaxella (Hübner, 1813)

N. swammerdamella (Linnaeus, 1758)

\section{Prodoxidae}

Lampronia flavimitrella (Hübner, 1817)

L. rupella (Denis \& Schiffermüller, I775)

\section{Incurvariidae}

Incurvaria pectinea Haworth, 1828

I. masculella (Denis \& Schiffermüller, 1775)

I. oehlmaniella (Hübner, 1796)

I. praelatella (Denis \& Schiffermüller, 1775)

\section{Tischeriidae}

Tischeria ekebladella (Bjerkander, 1795)

T. dodonea Stainton, 1858

T. decidua Wocke, 1876

Emmetia marginea (Wocke, 1871)

E. gaunacella (Duponchel), 1843)

E. angusticolella (Duponchel, 1843)

\section{Tineidae}

Cephimallota angusticostella (Zeller, 1839)

Reisserita rilicinella Zeller, 1839

Infurcitinae albicomella (Stainton, 1851)

I. finalis Gozmány, 1959

Stenoptinea cyaneimarmorella (Millére, 1854)

Scardia boletella (Fabricius, 1794)

Morophaga choragella (Denis \& Schiffermüller, 1775)

Archinemapogon yildizae Kocak, 1981

Triaxomera parasitella (Hübner, 1796)

Nemapogon cloacella (Haworth, 1828)

N. variegata (Clemens, 1859)

N. clematella (Fabricius, 1781) [1.] $]^{*}$

Neurothaumasia ankerella (Mann, 1867)

Trichophaga tapetzella (Linnaeus, 1758)

Tineola bisselliella (Hummel, 1823)

Tinea pellionella Linnaeus, 1758

T. semifulvella Haworth, 1828

T. trinotella Thunberg, 1794

Niditinea fuscella (Linnaeus, 1758)

Monopis laevigella (Denis \& Schiffermüller, 1775)

M. obviella (Denis \& Schiffermüller, 1775)

M. imella (Hübner, 1813)

M. monachella (Hübner, 1796)

$M$. fenestrella (Heyden, 1863)

Euplocamus anthracinalis (Scopoli, 1763)

\section{Lypusidae}

Lypusa maurella (Denis \& Schiffermüller, 1775)

\section{Psychidae}

Diplodoma laichartingella (Goeze, 1783)

Narycia astrella (Herrich-Schäffer, 1851)

Dahlica nickerlii (Heinemann, 1870)

Sideria pineti (Zeller, 1852)

Postsolenobia banatica (M. Hering, 1922)

Taleporia politella (Ochsenheimer, 1816)

T. tubulosa (Retzius, I783)

Proutia betulina (Zeller, I839)

Bruandia comitella (Bruand, 1853)

Bijugis bombycella (Denis \& Schiffermüller, 1775)

Rebelia herrichiella Strand, 1912

R. bavarica Wehrli, 1926

Psychidea nudella (Ochsenheimer, 1810) 
Epichnopterix plumella (Denis \& Schiffermüller, 1775)

E. kovácsi Sieder, 1955

Canephora hirsuta (Poda, 1761)

Pachythelia villosella (Ochsenheimer, 1810)

Megalophanes viciella (Denis \& Schiffermüller, 1775)

Ptilocephala muscella (Denis \& Schiffermüller, 1775)

Sterrhopterix fusca (Haworth, 1809)

Apterona crenulella (Bruand, 1853) (bisex. form) [2.]* vö. SZABÓKY, 1983, p.50.

\section{Roeslerstammiidae}

Roeslerstammia erxlebella (Fabricius, 1787)

R. pronubella (Denis \& Schiffermüller, 1775)

\section{Douglasiidae}

Tinagma perdicella Zeller, 1839

\section{Bucculatricidae}

Bucculatrix albedinella (Zeller, 1839)

B. bechsteinella (Bechstein - Scharfenberg, 1805)

B. cidarella (Zeller, 1839)

B. noltei Petry, 1912

B. maritima Stainton, 1851

B. frangutella (Goeze, 1783)

B. thoracella (Thunberg, 1794)

B. ulmella Zeller, 1848

\section{Gracillariidae}

Parectopa ononidis (Zeller,1839)

P. robiniella Clemens, 1863

Micrurapteryx kollariella (Zeller, 1839)

Caloptilia alchimiella (Scopoli, 1763)

C. cuculipennella (Hübner,1763)

C. elongella (Linnaeus, 1761)

C. falconipennella (Hübner, 1813)

(= oneratella Zeller, 1847)

C. fribergensis (Fritzsche, 1871)

C. fidella (Reutti, 1853)

C. honoratella (Rebel, 1914)

C. hauderi (Rebel, 1906)

C. hemidactylella (Denis \& Schiffermüller, 1775)

C. roscipennella (Hübner, 1796)

C. semifascia (Haworth, 1828)

C. stigmatella (Fabricius, 1781)

Gracillaria syringaria (Fabricius, 1794)

Aspilapteryx limosella (Duponchel, 1844)

A. tringipennella (Zeller, 1839)

Eucalybites auroguttella (Stephens, I 835)

Calybites phasianipennella (Hübner, 1813)

Sauterina hofmanniella (Schleich, I867)

Acrocercops brongniardella (Fabrïcius, 1789)

Povolnya leucopennella (Stephens, 1867)

Dialectica imparialella (Zeller, 1850)
Spuleriana simploniella (Fischer v. Röslerstamm, 1840)

Ornixola caudulatella (Zeller, 1839)

Callisto denticulella (Thunberg, 1794)

Parornix angelicella (Stainton, 1850)

$P$. anguliferella (Zeller, 1847)

P. betulae (Stainton, 1854)

P. carpinella (Frey, 1863)

P. finitimella (Zeller, 1850)

P. petiolella (Frey, 1863)

P. scoticella (Stainton, 1850)

P. torquillella (Zeller, 1850)

Phyllonorycter abrasella (Duponchel, 1843)

Ph. acerifoliella (Zeller, 1839)

Ph. blancardella (Fabricius, 1781)

Ph. cydoniella (Denis \& Schiffermüller, 1775)

$P h$ dubitella (Herrich-Schäffer, 1855)

Ph. emberizaepennella (Bouché, 1834)

Ph. froelichiella (Zeller, 1839)

Ph. harrisella (Linnaeus, 1761)

Ph. heegeriella (Staudinger, 1859)

Ph. kleemannella (Fabricius, 1781)

Ph. lantanella (Schrank, 1802)

Ph. mannii (Zeller, 1846)

Ph. muelleriella (Walsingham, 1908)

Ph. platani (Staudinger, 1870)

Ph. quercifoliella (Zeller, 1839)

Ph. rajella (Linnaeus, 1758)

Ph. roboris (Zeller, 1839)

Ph. sagitella (Bjerkander, 1790)

Ph. saportella (Duponchel, 1840)

Ph. scitulella (Duponchel, 1843)

Ph. sorbi (Frey, 1855)

Cameraria ohridella Deschka - Dimiè, 1986

Phyllocnistis saligana (Zeller, 1839)

\section{Yponomeutidae}

Scythropia crataegella (Linnaeus, 1767)

Yponomeuta evonymella (Linnaeus, 1758)

Y. cagnagella (Hübner, 1813)

Y. rorrella (Hübner, 1796)

$Y$. irrorella (Hübner, I796)

Y. plumbella (Denis \& Schiffermüller, 1775)

Y. sedella Treitschke, 1833

Pseudoswammerdamia combinella (Hübner, 1786)

Swammerdamia caesiella (Hübner, 1796)

S. pyrella (Villers, 1789)

Cedestis gysseleniella Zeller, 1839

Nimphonympha albella (Zeller, 1847)

Atemelia torquatella (Lienig - Zeller, 1846)

Argyresthia laevigatella (Heydenreich, 1861)

A. praecocella Zeller, 1839

A. brockeella (Hübner, 1813)

A. arceuthina Zeller, 1839 

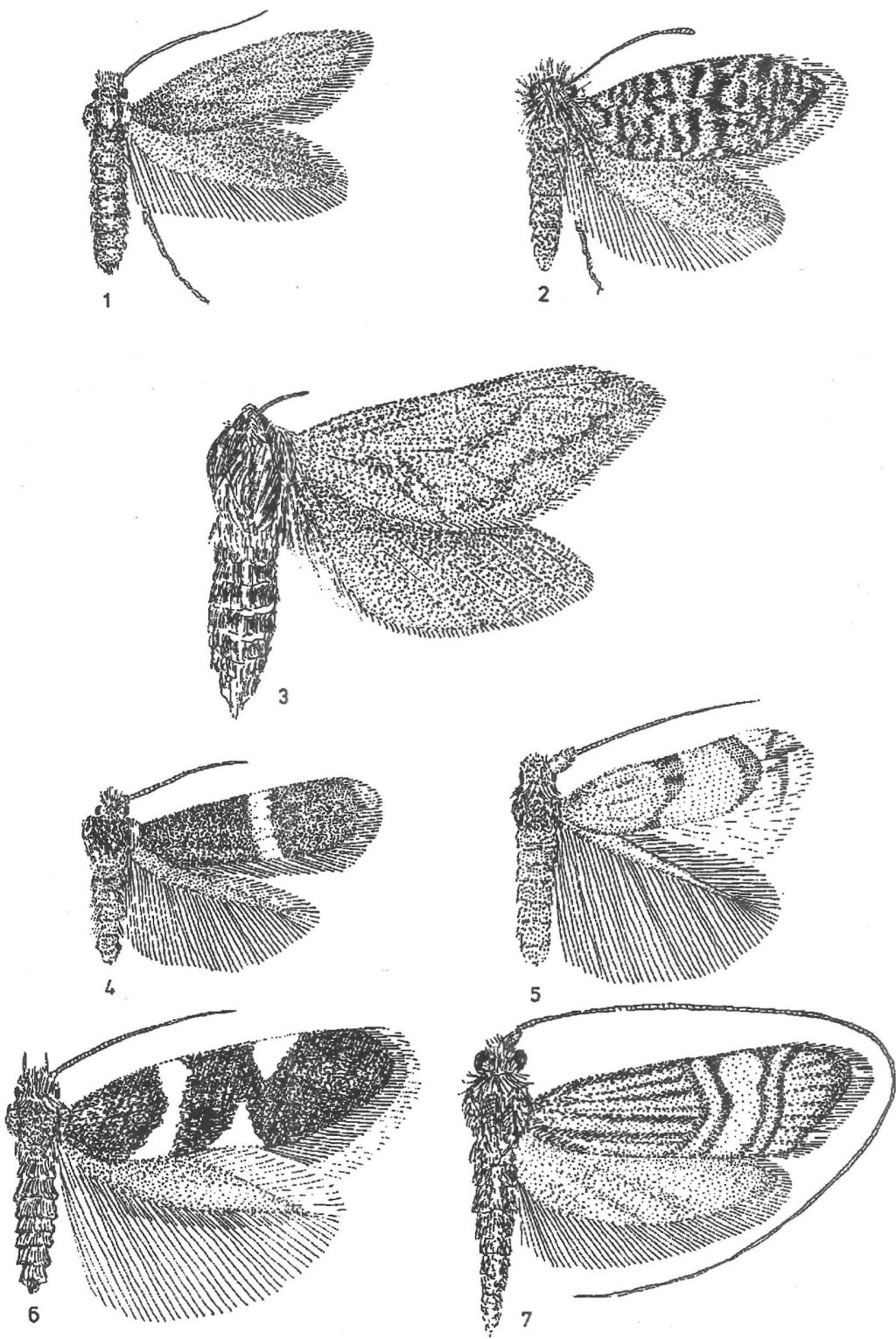

1-7. ábra: I= Micropterigidae, Micropterix calthella (Linnaeus, 1761); 2= Eriocraniidae, Eriocrania sparrmannella (Bosc, 1791); 3= Hepialidae, Hepialus humuli (Linnaeus, 1758); 4= Nepticulidae, Stigmella malella (Stainton, 1854); 5= Opostegidae, Pseudoopostega crepusculella (Zeller, 1839); 6= Heliozelidae, Antispila metalella (Denis \& Schiffermüller, 1775); 7= Adelidae, Nemaphora degeerella (Linnaeus, 1758). 


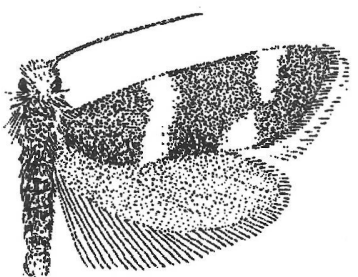

9

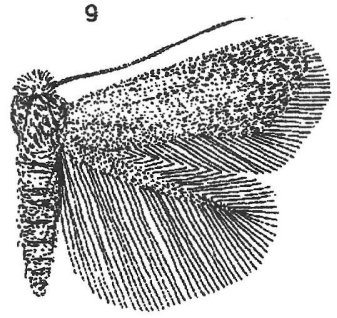

10

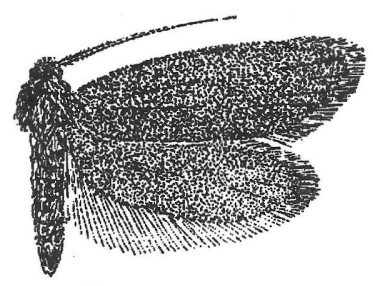

12

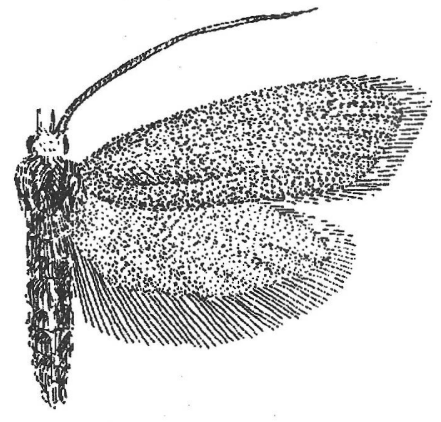

14

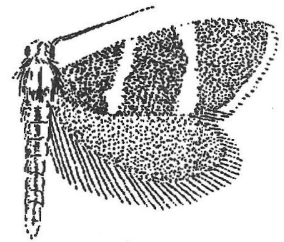

8
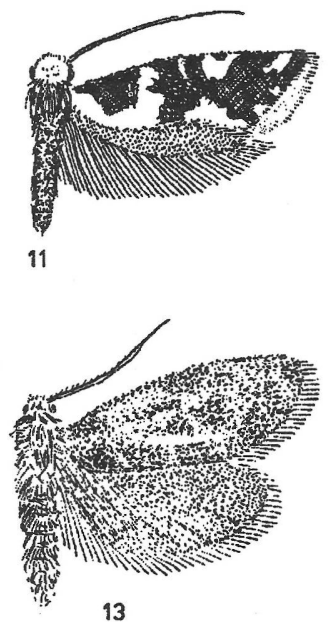

13

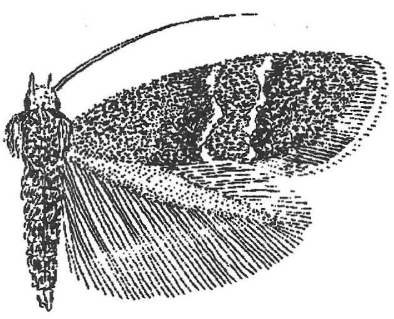

15

8-15. ábra: 8= Prodoxidae, Lampronia flavimitrella (Hübner, 1817); 9= Incurvariidae, Incurvaria praelatella (Denis \& Schiffermüller, 1775); 10= Tischeriidae, Tischeria decidua (Wocke, 1871); 11= Tineidae, Neurothaumasia ankerella (Mann, 1867); 12= Lypusidae, Lypusa maurella (Denis \& Schiffermüller, 1775); 13= Psychidae, Taleporia tubulosa (Retzius, 1783); 14= Roeslerstammidae, Roeslerstammia erxlebella (Fabricius, 1787); 15= Douglasiidae, Tinagma perdicella Zeller, 1839. 
A. dilectella Zeller, 1847

A. glaucinella Zeller, 1839

A. praecocella Zeller, 1839

A. abdominalis Zeller, 1839

A. goedartella (Linnaeus, 1758)

A. spinosella Stainton, 1849

A. pruinella (Clerck, 1759)

A. bonnetella (Linnaeus, 1758)

A. albistria (Haworth, 1828)

\section{Ypsolophidae}

Ypsolopha mucronella (Scopoli, 1763)

Y. asperella (Linnaeus, 1761)

Y. lacella (Fabricius, 1775)

Y. persicella (Fabricius, 1787)

Y. sylvella (Linnaeus, 1767)

Y. parenthesella (Linnacus, 1761)

Y. ustella (Clerck, 1759)

Y. chazariella (Mann, I866)

Ochsenheimeria taurella (Denis \& Schiffermüller, 1775)

\section{Plutellidae}

Plutella xylostella (Linnaeus, 1758)

Rhigognostis korácsi (Gozmány, 1952) [3.]*

Eidophasia messingiella (Fischer v. Röslerstamm, 1840)

\section{Acrolepiidae}

Digitivalva paleriella (Snellen, 1878)

D. pulicariae (Klimesch, 1956)

Acrolepia autumnitella (Curtis, 1838) (= pygmaeana Haworth, 1811)

\section{Glyphipterigidae}

Orthotelia sparganella (Thunberg, 1788)

Glyphipterix tharsonella (Scopoli, 1763)

G. bergstraesserella (Fabricius, 1781)

G. forsterella (Fabricius, 1781)

\section{Heliodinidae}

Heliodines roesella (Linnacus, 1758)

\section{Bedelliidae}

Bedellia ehikella Szöcs, 1967

B. somnulentella (Zeller, 1847)

\section{Lyonetiidae}

Leucoptera spartifoliella (Hübner, 1813)

L. heringiella Toll, 1938

L. sinuella (Reutti, 1853)

Ethmiidae

Ethmia dodecea (Haworth, 1828)

E. quadrillella (Goeze, 1783)

E. candidella (Alphéraky, 1908)
E. pusiella (Linnaeus, 1758)

E. terminella T. Fletcher, 1938

E. bipunctella (Fabricius, 1775)

E. haemorrhoidella (Eversmann, 1844)

\section{Depressariidae}

Semioscopis avellanella (Hübner, 1793)

S. steinkellneriana (Denis \& Schiffermüller, 1775

Luquetia lobella (Denis \& Schiffermüller, I775) Agonopterix ocella (Fabricius, 1775)

A. assimilella (Treitschke, 1832)

A. ciliella (Stainton, 1849)

A. arenella (Denis \& Schiffermüller, 1775)

A. propinquella (Treitschke, 1835)

A. laterella (Denis \& Schiffermüller, 1775)

A. curvipunctosa (Haworth, 1811)

A. yeatina (Fabricius, 1781)

A. alstromeriana (Clerck, 1759)

A. purpurea (Haworth, 1811)

A. heracliana (Linnaeus, 1758)

A. astrantiae (Heinemann, 1870)

A. oinochoroa (Turati, 1879)

A. pallorella (Zeller, 1839)

A. kaekeritziana (Linnaeus, 1767)

A. nervosa (Haworth, 1811)

Depressaria absynthiella Herrich-Schäffex, 1865

D. pastinacella (Duponchel, 1838)

D. depressana (Fabricius, 1775)

D. chaerophylli Zeller, 1839

D. ultimella Stainton, 1849

D. pimpinellae Zeller, 1839

D. emeritella Stainton, 1861

D. albipunctella (Denis \& Schiffermüller, 1775)

D. corticinella Zeller, 1854

D. cervinella Herrich-Schäffer, 1854

\section{Elachistidae}

Stephensia brunnichella (Linnaeus, 1767)

Elachista argentella (Clerck, 1759)

E. bedellella (Sircom, 1848)

E. bisulcella (Duponchel, 1843)

E. chrosodesmella Zeller, 1850

E. cingilella (Herrich-Schäffer, 1855)

E. dispilella Zeller, 1839

E. gangabella Zeller, 1850

E. gleichenella (Fabricius, 1781)

E. luticomella Zeller, 1839

E. monosemiella Rössler, 1881

E. pollinariella Zeller, 1839

E. pullicomella Zeller, 1839

E. serricornis Stainton, 1854

E. rufocinerea (Haworth, 1828)

E. subnigrella Douglas, 1853

E. triatomea (Haworth, 1828)

E. utonella Frey, 1856 
E. monosemiella Rössler, 1881

(= cerusella Hübner, 1796)

\section{Agonoxenidae}

Chrysoclista linneella (Clerck, 1759)

Blastodacna hellerella (Duponchel, 1838)

Spuleria flavicaput (Haworth, 1828)

Tetanocentria ochraceella Rebel, 1903

Deuterogoniidae

Deuterogonia pudorina (Wocke, 1857)

\section{Scythrididae}

Scythris obscurella (Scopoli, 1763)

S. laminella (Denis \& Schiffermüller, 1775)

S. limbella (Fabricius, 1775)

Parascythris muelleri (Mann, 1871)

Chimabachidae

Diurnea fagella (Denis \& Schiffermüller, 1775)

D. lipsiella (Denis \& Schiffermüller, 1775)

Dasytroma salicella (Hübner, 1796)

\section{Oecophoridae}

Bisigna procerella (Denis \& Schiffermüller, 1775)

Schiffermuelleria schaefferella (Linnaeus, 1758)

Denisia luctuosella (Duponchel, 1840)

D. augustella (Hübner, 1796)

Metalampra cinnamomea (Zeller, 1839)

$M$. diminutella (Rebel, 1931)

Endrosis sarcitrella (Linnaeus, 1758)

Hofmannophila pseudospretella (Stainton, 1849)

Borkhausenia minutella (Linnaeus, 1758)

Crassa tinctella (Hübner, 1796)

C. unitella (Hübner, 1796)

Batia lambdella (Donovan, 1793)

B. internella Jackh, 1972

Epicallima bruandella (Ragonot, 1889)

E. formosella (Denis \& Schiffermüller, 1775)

Esperia oliviella (Fabricius, 1794)

Oecophora bractella (Linnaeus, 1758)

Alabonia staintoniella (Zeller, 1850)

Harpella forficella (Scopoli, 1763)

Carcina quercana (Fabricius, 1775)

Minetia labiosella (Hübner, 1810)

M. criella (Treitschke, 1835)

Pleurota marginella (Denis \& Schiffermüller, 1775)

P. brevispinella (Zeller, 1847) [4.]*

$P$. pungitiella Herrich-Sch(ffer, 1852

P. pyropella (Denis \& Schiffermüller, 1775)

Holoscolia huebneri Kocak, 1980

Cephalispheira denisella (Denis \& Schiffermüller, 1775)

C. ferrugella (Denis \& Schiffermüller, 1775)

Stathmopoda pedella (Linnaeus, 1761)
Lecithoceridae

Homaloxestis briantiella (Turati, I879)

\section{Batracheridae}

Batrachedra praeangusta (Haworth, 1828)

B. pinicolella (Zeller, 1839)

Coleophoridae

Augasina aeratella (Zeller, 1839)

Metriotes lutarea (Haworth, 1828)

Coleophora limosipennella (Duponchel, 1843)

C. orbitella Zeller, 1849

C. binderella (Kollar, 1852)

C. serratella (Linnacus, 1761)

C. ahenella Heinemann, 1876

C. albitarsella Zeller, 1846

C. frischella (Linnaeus, 1758)

C. alcyonipennella (Kollar, 1832)

C. trifariella Zeller, 1849

C. hemerobiella (Scopoli, 1763)

C. lithargyriella Zeller, 1849

C. niveicostella Zeller, 1839

C. deauratella Lienig ( Zeller, 1846

C. ballotella (Fischer v. Röslerstamm, 1839)

C. albidella (Denis \& Schiffermüller, 1775)

C. kuehnella (Goeze, 1783)

C. zelleriella Heinemann, 1854

C. currucipennella Zeller, 1839

C. virgatella Zeller, 1849

C. chamaedriella Bruand, 1852

C. serpylletorum E. Hering, 1889

C. gallipennella (Hübner, 1796)

C. coronillae Zeller, 1849

C. fuscociliella Zeller, 1849

C. caelebipennella Zeller, 1839

C. lixella Zeller, 1849

C. halophilella Zimmermann, 1926

C. tanacețivaühlig, 1865

C. gnaphalii Zeller, 1839

C. galbulipennella Zeller, 1838

C. trochiella (Duponchel, 1843)

C. pibicigerella Zeller, 1839

C. conspicuella Zeller, 1849

C. partiella Zeller, 1849

C. vibicella (Hübner, 1813)

C. fuscociliella Zeller, 1849

C. lixella Zeller, 1849

C. ornatipennella (Hübner, 1796)

C. vulnerariae Zeller, 1839

C. caespititella Zeller, 1839

C. glaucicolella Wood, 1892

C. otidipennella (Hübner, 1817) [5.]*

C. motacillella Zeller, 1849

C. squamosella Stainton 1856

C. millefolii Zeller, 1849 


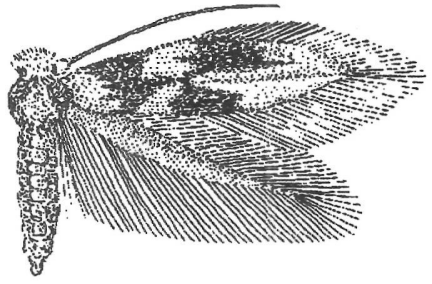

16
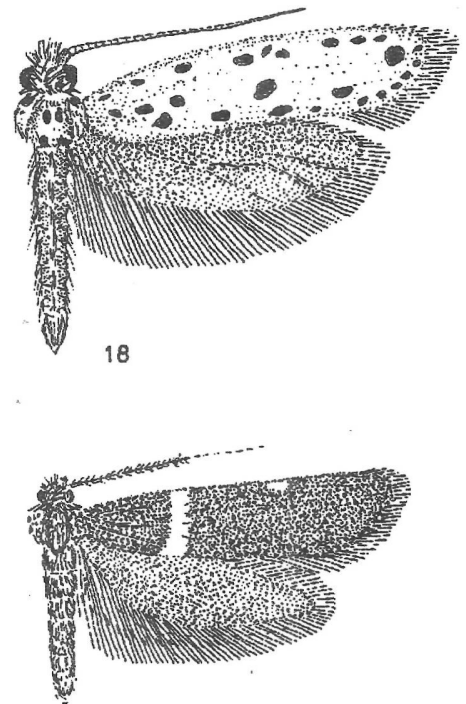

20

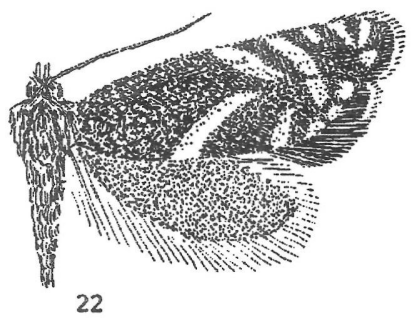

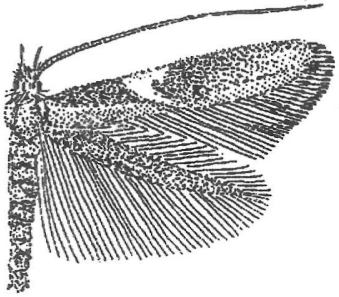

17

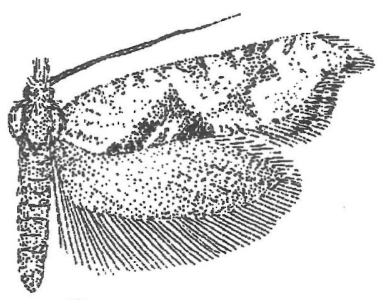

19

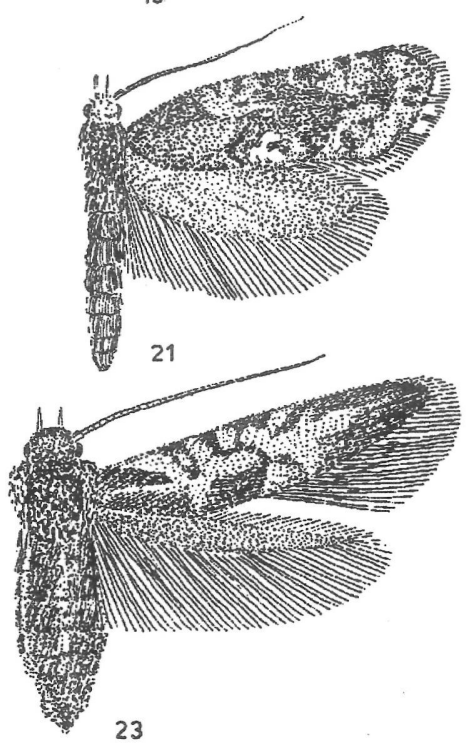

16-23. ábra: 16= Bucculatricidae, Bucculatrix thoracella (Thunberg, 1794); 17= Gracillariidae, Caloptilia stigmatella (Fabricius, 1781); 18= Yponomeutidae, Yponomeuta cagnagella (Hübner, 1813); 19= Ypsolophidae, Ypsolopha asperella (Linnaeus, 1761); $20=$ Plutellidae, Eidophasia messingiella (Fischer v. Röslerstamm, 1840); 21 = Acrolepiidae, Acrolepia autumnitella (Curtis, 1838); 22= Glyphipterigidae, Glyphipterix forsterella (Fabricius, 1781); 23= Heliodinidae, Heliodines rosella (Linnaeus, 1758). 

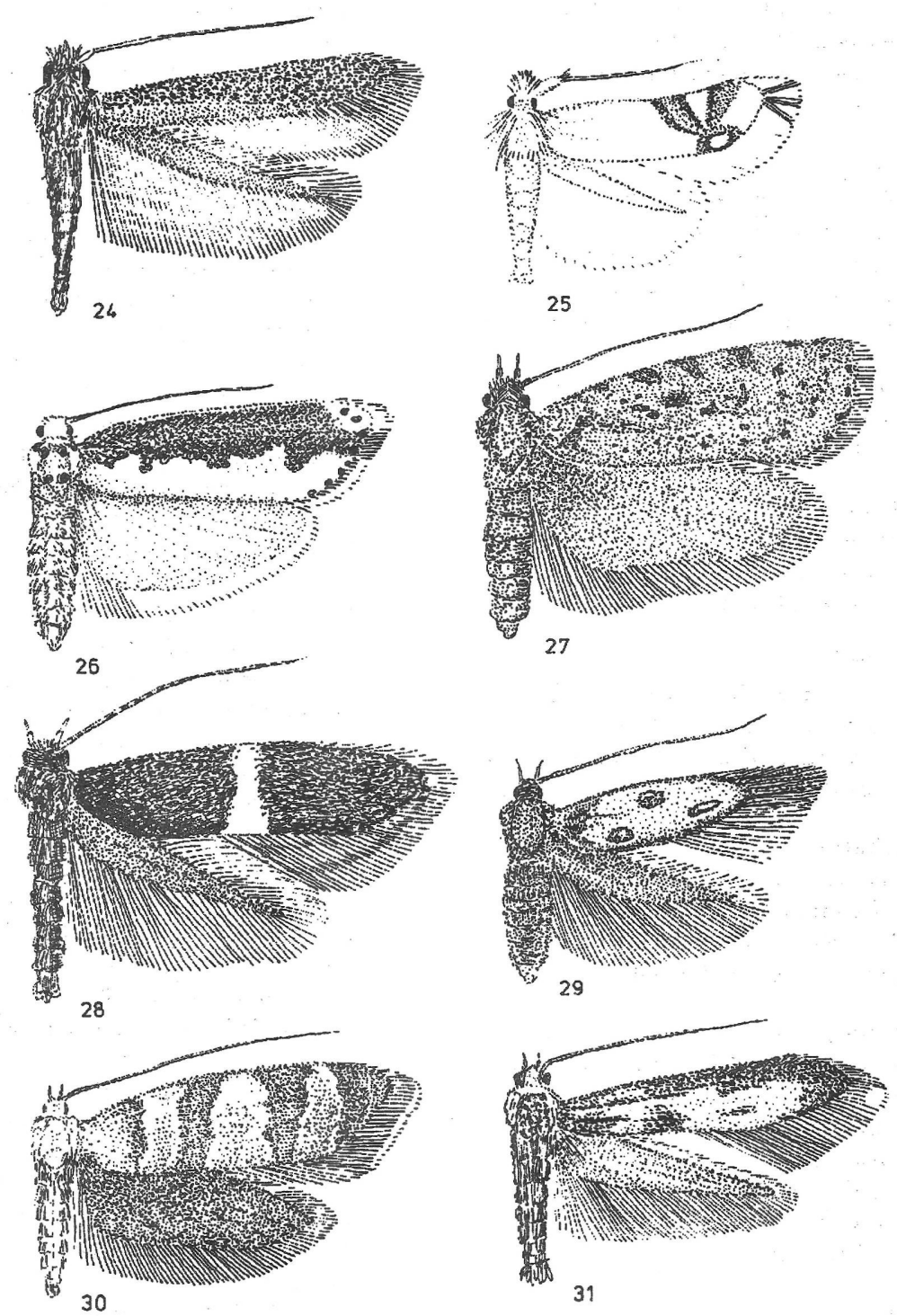

24-31. ábra: 24= Bedlelliidae, Bedellia somnulentella (Zeller, 1847); 25= Lyonetiidae, Leucoptera sinuella (Reutti, 1853); 26= Ethmiidae, Ethmia bipunctella (Fabricius, 1775); 27= Depressariidae, Agonopterix arenella (Denis \& Schiffermüller, 1775); 28= Elachistidae, Elachista chrysodesmella Zeller, 1850; 29= Agonoxenidae, Chrysoclista linneella (Clerck, 1759); $30=$ Deuteroginiidae, Deuterogina pudorina (Wocke, 1857); 31 = Scythrididae, Scythris limbella (Fabricius, 1775). 

C. striatipennella Nylander, 1848
C. solitariella Zeller, 1849
C. clypeiterella O. Hoffmann, 1871
C. squlorella Zeller, 1849
C. salicorniae Heinemann (Wocke, 1876)
C. unipunctella Zeller, I 849

\section{Momphidae}

Psacaphora locupletella (Denis \& Shciffermüller, 1775)

Mompha ochraceella (Curtis, 1839)

M. propinquella (Stainton, 185I)

M. divisiella Herrich-Schäffer, I 854 [6.]*

M. bradley Riedl, 1965

M. epilobiella (Denis \& Schiffermüller, 1775)

M. stumipennella (Treitschke, I 833)

(= nodicolella Fuchs, 1902)

\section{Blastobasidae}

Blastobasis phycidella (Zeller, 1839)

Hypatopa binotella (Thunberg, 1794)

H. binotella (Thunberg, 1794)

\section{Autostichidae}

Oegoconia deauratella (Herrich-Schäffer, I 854)

O. quadripuncta (Haworth, I 828)

Apatema mediopallidum Walsingham, 1900

Donaspastus pannonicus Gozmány, 1952

\section{Amphisbatidae}

\section{8}

Pseudatemelia josephinae (Toll, 1956)

P. subochreella (Doubleday, 1859)

P. flavifrontella (Denis \& Schiffermüller, 1775)

Hypercalis citrinalis (Scopoli, 1763)

\section{Cosmpoterigidae}

Pancalia leuwenhoekella (Linnaeus, 1761)

Limnaecia phragmitella Stainton, 1851

Pyroderces argyrogrammos (Zeller, 1847)

P. klimeschi Rebel, 1938 [7.]*

Cosmopterix zieglerella (Hübner, 1810)

C. scribaiella Zeller, 1850

C. orichalcea Stainton, 1861

\section{Gelechiidae}

Caulastrocecis furfurella (Staudinger, 1871)

Megacraspedus dolosellus (Zeller, I839)

Aristotelia decurtella (Hübner, 1813)

A. subericinella (Duponchel, 1843)

Chrysoestia drurella (Fabricius, 1775)

C. sexguttella (Thunberg, 1794)

Xystophora pulveratella (Herrich-Schäffer, 1854)

Altremaea lonchoptera Staudinger, 1871

Isophrictis striatella (Denis \& Schiffermuiller, 1775)

Metzneria paucipunctella (Zeller, 1839)

M. lappella (Linnaeus, 1758)
M. metzneriella (Stainton, 1851)

Apodia bifractella (Duponchel, 1843)

Ptocheuusa inopella (Zeller, 1839)

P. paupella (Zeller, 1847)

Monochroa sepicolella (Herrich-Schäffer, 1854)

(= balcanica Rebel, 1903;

agasta Gozmány, 1954)

M. servella (Zeller, 1839)

$$
\text { (= brunickii Rebel, 1913) }
$$

M. conspersella (Herrich-Schäffer, 1854)

M. elongella (Heinemann, 1870)

M. homigi (Staudinger, 1883)

M. lucidella (Stephens, 1834)

M. divisiella (Douglas, 1850) [8.]*

M. palustrella (Douglas, 1850)

Eulamprotes wilkella (Linnaeus, 1758)

E. unicolorella (Duponchel, 1843)

E. atrella (Denis \& Schiffermüller, 1775)

Bryotopha affinis (Haworth, 1828)

Recurvaria nanella ([Denis \& Schiffermüller], 1775)

R. leucatella (Clerck, 1759)

Stenolechia gemmella (Linnaeus, 1758)

Teleiodes luculella (Hübner, [1813])

Carpatolechia albumella (Zeller, 1839)

C. notatella (Hübner, 1813)

T. proximella (Hübner, 1796)

Teleiopsis diffinis (Haworth, 1928)

Pseudotelphusa scalella (Scopoli, 1763)

P. paripuctella (Thunberg, 1794)

Altenia scriptella (Hübner, 1796)

Gelechia scotinella Herrich-Schäffer, 1854

G. sabinellus (Zeller, 1839)

G. muscosella Zeller, 1839

G. scotinella Herrich-Schäffer, 1854

G. muscosella Zeller, 1839

G. nigra (Haworth, 1828)

G. turpella ([Denis \& Schiffermüller], 1775)

Mirificarma eburnella ([Denis \& Schiffermüller], 1775) (= formosella Hübner, 1796)

Mirificarma lentiginosella (Zeller, 1839)

M. cytisella (Treitschke, 1833)

Chionodes distinctella (Zeller, 1839)

C. electella (Zeller, 1839)

Aroga velocella (Zeller, 1839)

A. flavicomella (Zeller, 1839)

Athrips rancidella (Herrich-Schäffer, 1854)

Prolita solutella (Zeller, 1839)

Scrobipalpa acuminatella (Sircom, 1850)

Scrobipalpa atriplicella (Fischer v. Röslerstamm, 1841)

S. hungariae (Staudinger, 1871) [9.]*

S. ocellatella (Boyd, 1858)

Cosmardia moritzella (Treitschke, 1835)

Ephysteris promptella (Staudinger, 1859) 
Caryocolum tricolorella (Haworth, 1812)

C. leucothoracellum (Klimesch, 1953)

C. blandella (Douglas, 1852)

C. proxima (Haworth, 1828)

Sophronia semicostella (Hübner, 1813)

S. illustrella (Hübner, 1796)

S. ascalis Gozmány, 1951 [10.]*

S. sicariellus (Zeller, 1839)

Syncopacma coronillella (Treitschke, 1833)

S. cinctella (Clerck, 1759)

S. ochrofasciella (Toll, 1939)

S. taeniolella (Zeller, 1839)

S. albifrontella (Heinemann, 1870)

S. vinella (Bankes, 1898)

S. captivella (Herrich-Schäffer, 1854) (= sarothamnella Zeller, 1868)

S. albipalpella (Herrich-Schäffer, 1854) [11.]* Aproaerema anthyllidella (Hübner, 1813) Anacampis populella (Clerck, 1759)

A. blattariella (Hübner, 1796)

A. timidella (Wocke, I887)

Mesophles silacella (Hübner, 1796)

Crossobella trinotella (Herrich-Schäffer, 1856)

Anarsia lineatella Zeller, 1839

A. spartiella (Schrank, 1802)

Nothris verbascella (Denis \& Schiffermüller, 1775)

Dichomeris marginella (Fabricius, 1781)

D. ustalella (Fabricius, 1794)

D. derasella (Denis ( Schiffermüller, 1775)

D. limosellus (Schl(ger, 1849)

D. barbella (Denis ( Schiffermüller, 1775)

D. alacella (Zeller, 1839)

Anasphaltis renigerellus (Zeller, 1839)

Brachmia dimidiella (Denis \& Schiffermüller, 1775)

B. blandella (Fabricius, 1798)

B. inornatella (Douglas, 1850)

Helcystogramma lineolella (Zeller, 1839)

H. lutatella (Herrich-Schäffer, 1854)

H. rufescens (Haworth, 1828)

H. triannulella (Herrich-Schäffer, 1854)

H. albinervis (Gerasinov, 1929)

H. arulensis (Rebel, 1929)

Acompsia cinerella (Clerck, 1759)

Pexicopia malvella (Hübner, 1805)

Platyedra subcinerea (Haworth, 1828)

Sitotroga ceralella (Olivier, 1789)

\section{Limacodidae}

Apoda limacodes (Hufnagel, 1766)

Heterogenea asella (Denis \& Schiffermüller, 1775)

\section{Zygaenidae}

Theresimima ampelophaga (Bayle - Barelle, 1808) Rhagades pruni (Denis \& Schiffermüller, 1775) Jordanita subsolana (Staudinger, 1862)
J. chloros (Hübner, 1813)

J. globulariae (Hübner, 1793)

Adscita geryon (Hübner, 1813)

A. statices (Linnaeus, 1758)

Zygaena brizae (Esper, 1800)

Z. minos (Denis \& Schiffermüller, 1775)

Z. purpuralis (Brünnich, 1763)

Z. carniolica (Scopoli, 1763)

Z. loti (Denis \& Schiffermüller, 1775)

Z. osterodensis Reiss, 1921

(Megjegyzés: elófordulása kérdéses.)

Z. viciae (Denis \& Schiffermüller, 1775)

Z. ephialtes (Linnaeus, 1767)

Z. filipendulae (Linnaeus, 1758)

Z. lonicerae (Scheven, 1777)

Z. trifolii (Esper, 1783) [12.](

\section{Brachodidae}

Brachodes nana (Treitschke, 1834) [13.]*

\section{Sesiidae}

Sesia apiformis (Clerck, 1759)

Paranthrene tabaniformis (Rottemburg, 1775)

Synanthedon spheciformis (Denis - Schiffermüller, 1775)

S. stomoxiformis (Hübner, 1790)

S. mesiaeformis (Herrich-Schäffer, 1846) [14.]*

S. culiciformis (Linnaeus, 1758)

S. formicaeformis (Esper, 1783)

S. pespiformis (Linnaeus, 1761)

S. myopaeformis (Borkhausen, 1789)

S. conopiformis (Esper, 1782)

S. tipuliformis (Clerck, 1759)

S. spuleri (Fuchs, 1908)

S. loranthi (Králièek, 1966)

Bembecia ichneumoniformis (Denis \& Schiffermüller, 1775)

B. scopigera (Scopoli, 1763)

B. uroceriformis (Treitschke, 1834)

Synansphecia triannuliformis (Freyer, 1845)

Chamaesphecia annellata (Zeller, 1847)

C. sevenari Lipthay, 1961

C. euceraeformis (Ochsenheimer, 1816)

C. tenthrediniformis (Denis \& Schiffermüller, 1775)

C. astatiformis (Herrich-Schäffer, 1846)

C. empiphormis (Esper, 1783)

C. leucopsiformis (Esper, 1800)

\section{Cossidae}

Cossus cossus (Linnaeus, 1758)

Lamellocossus terebra (Denis \& Schiffermüller, 1775) [15.]*

Dyspessa ulula (Borkhausen, 1790)

Zeuzera pyrina (Linnaeus, 1761)

Phragmataecia castaneae (Hübner, 1790) 


\section{Tortricidae}

Phtheochroa inopiana (Haworth, 1811)

Ph. schreibersiana (Frölich, 1828)

Ph. pulvillana (Herrich-Schäffer, 1851)

Cochylimorpha hilarana (Herrich-Schaffer, 1851)

C. straminea (Haworth, 1811)

Phalonidia contractana (Zeller, I 847)

Ph. permixtana (Denis \& Schiffermüller, 1775)

Agapeta hamana (Linnaeus, 1758)

A. zoegana (Linnaeus, 1767)

Eupoecilla angustana (Hübner, 1799)

E. ambiguella (Hübner, 1796)

Aethes hartmanniana (Clerck, 1759)

Ae. margarotana (Duponchel, 1836)

Ae. margaritana (Haworth, 1811)

Ae. rutilana (Hübner, 1817)

Ae. smeathmanniana (Fabricius, 1781)

Ac. tesserana (Denis \& Schiffermüller, 1775)

Ae. sanguinana (Treitschke, 1830)

Ae. flagellana (Duponchel, 1836 )

Ae. rubigiana (Treitschke, 1830)

Ae. kindermanniana (Treitschke, 1830)

Cochylidia subroseana (Haworth, 1811)

C. implicitana (Wocke, 1856)

Diceratura ostrinana (Guenée, 1845)

Cochylis nana (Haworth, 1811)

C. epilinana (Duponchel, 1842)

C. hybridella (Hübner, 1813)

C. pallidana (Zeller, 1847)

C. posterana (Zeller, 1847)

Falseuncaria ruficiliana (Haworth, 1811)

Tortrix piridana Linnaeus, 1758

Aleimma loeflingiana (Linnaeus, 1758)

Acleris forsskaleana (Linnaeus, 1758)

A. sparsana (Denis \& Schiffermüller, 1775)

A. rhombana (Denis \& Schiffermüller, 1775)

A. schalleriana (Linnaeus, 1761)

A. lorquiniana (Duponchel, 1835)

A. variegana (Denis \& Schiffermüller, 1775)

A. hastiana (Linnaeus, 1775)

A. permutana (Duponchel, 1836)

A. ferrugana (Denis \& Schiffermüller, 1775)

A. notana (Donovan, 1806)

A. kochiella (Goeze, 1783) [16.]*

A. logiana (Clerck, 1759)

A. literana (Linnaeus, 1758)

Neosphaeleroptera nubilana (Hübner, 1799)

Doloploca punctulana (Denis \& Schiffermüller, 1775)

Tortricodes alternella (Denis \& Schiffermüller, 1775)

Cnephasia incertana (Treitschke, 1835)

C. abrasana (Duponchel, 1843)

C. communana (Herrich-Schäffer, 1851)

Eulia ministrana (Linnaeus, 1758)
Psudoargyrotoza conwagana (Fabricius, 1775)

Epagoge grotiana (Fabricius, 1781)

Paramesia gnomana (Clerck, 1759)

Periclepsis cinctana (Denis \& Schiffermüller, 1775)

Philedone gerningana (Denis \& Schiffermüller, 1775)

Pseudeulia asiana (Hübner, 1799)

Capua pulgana (Frölich, 1828)

Archips oporana (Linnaeus, 1758)

A. podana (Scopoli, 1763)

A. crataegana (Hübner, 1799)

A. xylosteana (Linnaeus, 1758)

A. rosana (Linnaeus, 1758)

Choristoneura hebenstreitella (Müller, 1764)

Argyrotaenia ljungiana (Thunberg, 1797)

Ptylocholoma lecheana (Linnaeus, 1758)

Pandemis corylana (Fabricius, 1794)

P. cerasana (Hübner, 1786)

$P$. heparana (Denis \& Schiffermüller, 1775)

P. dumetana (Treitschke, 1835)

Syndemis musculana (Hübner, 1799)

Aphelia paleana (Hübner, 1793)

A. ochreana (Hübner, 1799)

A. vibumana (Denis \& Schiffermüller, 1775)

Clepsis rurinana (Linnaeus, 1758)

C. spectrana (Treitschke, 1830)

C. pallidana (Fabricius, 1776)

Adaxophyes orana (Fischer v. Röslerstamm, 1834)

Bactra lancealana (Hübner, 1799)

B. furfurana (Haworth, 1811)

B. robustana (Christoph, 1872)

Endothenia gentianaeana (Hübner, 1799)

E. marginana (Haworth, 1811)

E. nigricostana (Haworth, 1811)

E. quadrimaculana (Haworth, I811)

Selenodes karelica (Tenström, 1875)

Apotomis semifasciana (Haworth, 1811)

A. lineana (Denis \& Schiffermüller, 1775)

A. turbidana (Hübner, 1825)

A. capreana (Hübner, 1817)

A. sororculana (Zetterstedt, 1839)

Orthotaenia undulana (Denis \& Schiffermüller, 1775)

Hedya salicella (Linnaeus, 1758)

H. nubiferana (Haworth, 1811)

H. pruiana (Hübner, 1799)

Metendothenia atropunctana (Zetterstedt, 1839) [17.]*

Celypha rufana (Scopoli, 1763)

C. striana (Denis \& Schiffermüller, 1775)

C. flavipalpana (Herrich-Schäffer, 1851)

C. capreolana (Herrich-Schäffer, 1851)

C. cespitana (Hübner, 1817)

C. lacunana (Denis \& Schiffermüller, 1775)

C. rivulana (Scopoli, 1763) 
C. doubledayana (Barret, I 872)

Peristerognatha fuligana (Denis - Schiffermüller, 1775) [18. $]^{*}$

Olethreutes arcuella (Clerck, 1759)

Piniphila bifasciana (Haworth, 1811)

Lobesia euphorbiana (Freyer, 1842)

Lobesia botrana (Denis \& Schiffermüller, 1775)

L. reliquana (Hübner, 1825)

L. bicinctana (Duponchel, 1844)

Rhopobota naevana (Hübner, 1817)

Thiodia citrana (Hübner, 1799)

Spilonota ocellana (Denis \& Schiffermüller, 1775)

S. laricana (Heinemann, 1863)

Gibberifera simplana (Fischerv Röslerstamm, 1836)

Epinotia trigonella (Linnaeus, 1758)

E. granitana (Herrich-Schäffer, 1851)

E. tetraquetrana (Haworth, 1811)

E. ramella (Linnaeus, 1758)

E. tedella (Clerck, 1759)

E. nisella (Clerck, 1759)

Zeiraphera griseana (Hübner, 1799)

Z. rufimitrana (Herrich-Schäffer, 1851)

Z. isertana (Fabricius, 1794)

Pelochrista decolorana (Freyer, 1842)

P. caecimaculana (Hübner, 1799)

$P$. infidana (Hübner, 1824)

Eucosma obumbratana (Lienig - Zeller, 1846)

E. cana (Haworth, 1811)

E. hohenwartiana (Denis \& Schiffermüller, 1775)

E. fulvana (Stephens, 1834)

E. lacteana (Treitschke, 1835)

E. albidulana (Herrich-Schäffer, 1851)

E. metzneriana (Treitschke, 1830)

E. conterminana (Guenée, 1845)

E. aspidiscana (Hübner, 1817)

Gypsonoma minutana (Hübner, 1799)

G. dealbana (Frölich, 1828)

G. nitidulana (Lienig - Zeller, 1846)

G. sociana (Haworth, 1811)

G. aceriana (Duponchel, 1843)

Epiblema sticticana (Fabricius, 1794)

E. scutulana (Denis \& Schiffermüller, 1775)

E. foenella (Linnaeus, 1758)

E. junctana (Herrich-Schäffer, 1856)

Notocelia cynosbatella (Linnaeus, 1758)

N. uddmanniana (Linnaeus, 1758)

N. roborana (Denis \& Schiffermüller, 1775)

N. trimaculana (Haworth, 1811)

Blastesthia turionella (Linnaeus, 1758)

Retinia resinella (Linnaeus, 1758)

Rhyacionia buoliana (Denis \& Schiffermüller, 1775)

R. pinivorana (Lienig - Zeller, 1846)

$R$. duplana (Hübner, 1813)

Enarmonia formosana (Scopoli, 1763)
Ancylis uncella (Denis \& Schiffermüller, 1775)

A. laetana (Fabricius, 1775)

A. obtusana (Haworth, 1811)

A. comptana (Frölich, 1828)

A. diminutana (Haworth, 1811) [19.]*

A. selanana (Guenée, 1845)

A. unculana (Haworth, 1811)

A. apicella (Denis \& Schiffermüller, 1775)

A. paludana Barret, 1886

A. badiana (Denis \& Schiffermüller, 1775)

A. achatana (Denis \& Schiffermüller, 1775)

A. mitterbacheriana (Denis \& Schiffermüller, 1775)

Cydia fissana (Frölich, 1828)

C. compositella (Fabricius, 1775)

C. pallifrontana (Lienig - Zeller, 1846)

C. coronillana (Lienig - Zeller, 1846)

C. discretana (Wocke, 1861)

C. lathyrana (Hübner, 1822)

C. funebrana (Treitschke, 1835)

C. janthiana (Duponchel, 1843)

C. lobarzewskii (Nowicki, 1860)

C. molesta (Busck, 1916)

C. nigricana (Fabricius, 1794)

C. oxytropidis (Martini, 1912)

C. succedana (Denis \& Schiffermüller, 1775)

C. conicolana (Heylaerts, 1874)

C. coniferana (Saxesen, 1840)

C. pactolana (Zeller, 1840)

C. pomonella (Linnaeus, 1758)

C. pyrivora (Danilevsky, 1947)

C. servillana (Duponchel, 1836)

C. splendana (Hübner, 1799)

C. fagiglandana (Zeller, 1841)

C. amplana (Hübner, 1800)

Lathronympha strigana (Fabricius, 1775)

Pammene fasciana (Linnaeus, 1761)

P. splendidulana (Guenée, 1845)

P. inquiliana T. Fletcher, 1938

$P$. argyrana (Hübner, 1799)

$P$. rhediella (Clerck, 1759)

P. trauniana (Denis \& Schiffermüller, 1775)

P. ochsenheimeriana (Lienig - Zeller, 1846)

$P$. germmana (Hübner, 1799)

Strophedra nitidana (Fabricius, 1794)

Dichrorampha plumbana (Scopoli, 1763)

D. acuminatana (Lienig - Zeller, 1846)

D. gueneeana Obraztsov, 1953

D. petiverella (Linnaeus, 1758)

\section{Choreutidae}

Anthophila fabriciana (Linnaeus, 1767)

Prochoreutis myllerana (Fabricius, 1794)

Tebenna micalis (Mann, 1857)

Choreutis pariana (Clerck, 1759) 
Urodidae

Wockia asperipunctella (Bruand, 1851)

\section{Schreckensteiniidae}

Schreckensteinia festaliella (Hübner, 1819)

\section{Epermeniidae}

Epermenia insecurella (Stainton, 1849)

E. aequidentella (E. Hoffmann, 1867)

E. chaerophyllella (Goeze, 1783)

E. illigerella (Hübner, 1813)

Ochromolopis ictella (Hübner, 1813)

\section{Alucitidae}

Alucita grammodactyla Zeller, 1841

A. desmodactyla Zeller, 1847

\section{Pterophoridae}

Agdistis adactyla (Hübner, 1819)

Platyptilia gonodactyla (Denis \& Schiffermüller, 1775)

Amblyptilia acanthodactyla (Hübner, 1813)

A. punctidactyla (Haworth, 1811)

Stenoptilia pterodactyla (Linnaeus, 1761)

S. bipunctidactyla (Scopoli, 1763)

Cnaemidophorus rhododactylus (Denis \& Schiffermüller, 1775)

Oxyptilus pilosellae (Zeller, 1841)

$O$. distans (Zeller, 1847)

O. tristis (Zeller, 1841)

Geina didactyla (Linnaeus, 1758)

Pterophorus pentadactylus (Linnaeus, 1758)

Porrittia galactodactyla (Denis \& Schiffermüller, 1775)

Merrifieldia leucodactyla (Denis \& Schiffermüller, 1775)

Merrifieldia malacodactyla transdanubinus (Fazekas, 1986) [20.]*

Hellinsia tephradactyla (Hübner, 1813)

$H$. didactylites (Ström, 1783)

H. carphodactyla (Hübner, 1813)

H. inulae (Zeller, 1852)

H. lienigianus (Zeller, 1852)

Adaina microdactyla (Hübner, 1813)

Emmelina monodactyla (Linnaeus, 1758)

E. argoteles (Meyrick, 1922)

\section{Thyrididae}

Thyris fenestrella (Scopoli, 1763)

\section{Pyralidae}

Aphomia sociella (Linnaeus, 1758)

A. foedella (Zeller, I 839)

A. zelleri Joannis, 1932

Lamoria anella (Denis \& Schiffermüller, 1775)

Galleria mellonella (Linnaeus, 1758)
Synaphe punctalis (Fabricius, 1775)

Pyralis regalis (Denis \& Schiffermüller, 1775)

P. farinalis (Linnaeus, 1758)

Aglossa signicostalis Staudinger, 1871

A. pinguinalis (Linnaeus, 1758)

Actenia brunnealis (Treitschke, 1829)

A. honestalis (Treitschke, 1829)

Hypsopygia costalis (Fabricius, 1775)

Herculia fulvocilialis (Duponchel, 1834)

$H$. incarnatalis (Zeller, 1847)

H. rubidalis (Denis \& Schiffermüller, 1775)

Orthopygia glaucinalis (Linnaeus, 1758)

Endotricha flammealis (Denis \& Schiffermüller, 1775)

Cryptoblabes bistriga (Haworth, 1811)

Trachonitis cristella (Denis \& Schiffermüller, 1775)

Salebriopsis albicilla (Herrich-Schäffer, 1849)

Elegia fallax (Staudinger, 1881)

E. similella (Zincken, 1818)

Ortholepis betulae (Goeze, 1778)

Pempeliella ornatella (Denis \& Schiffermüller, 1775)

P. dilutella (Denis \& Schiffermüller, 1775)

Catastia marginea (Denis \& Schiffermüller, 1775)

Khorassania compositella (Treitschke, 1835)

Serrulacera serraticomella (Zeller, 1839)

Sciota fumella (Eversmann, I 844)

S. rhenella (Zincken, 1818)

S. adelphella (Fischer v. Röslerstamm, 1836)

Selagia argyrella (Denis \& Schiffermüller, 1775)

Etiella zinckenella (Treitschke, 1832)

Oncocera semirubella (Scopoli, 1763)

O. faecella (Zincken, 1839)

Pempelia formosa (Haworth, 1811)

P. palumbella (Denis \& Schiffermüller, 1775)

Psorosa dahliella (Treitschke, 1832)

Dioryctria sylvestrella (Ratzenburg, 1840)

D. simplicella Heinemann, 1863

D. abietella (Denis \& Schiffermüller, 1775)

Phycita roborella (Denis \& Schiffermüller, 1775)

Hypochalcia ahenella (Denis \& Schiffermüller, 1775)

Epischnia prodromella (Hübner, 1799)

Conobathra tumidana (Denis \& Schiffermüller, 1775)

Trachycera advenella (Zincken, 1818)

T. legatea (Haworth, 1811)

T. suavella (Zincken, 1818)

T. dulcella (Zincken, 1848)

T. marmorea (Haworth, 1811)

Acrobasis sodalella Zeller, 1848

A. consociella (Hübner, 1813)

A. glaucella Staudinger, 1859

A. obtusella (Hübner, 1796)

Glyptoteles leucacrinella Zeller, 1848 
Episcythrastis tericella (Denis \& Schiffermüller, 1775)

Eurhodope rosella (Scopoli, 1763)

Myelois circumvoluta (Fourcroy, 1785)

Myelopsis tetricella ([Denis \& Schiffermüller], 1775)

Isauria dilucidella,(Duponchel, 1836)

Eccopisa effractella Zeller, 1848

Euzophera pinguis (Haworth, 1811)

E. bigella (Zeller, 1848)

E. cinerosella (Zeller, 1839)

E. fuliginosella (Heinemann, 1865)

Euzophorodes charlottae (Rebel, 1914)

Nyctegretis lineana (Scopoli, 1786)

N. triangulella Ragonot, 1901

Ancylosis cinnamomella (Duponchel, 1836)

A. oblitella (Zeller, 1848)

Homoeosoma sinuella (Fabricius, 1794)

H. nebulella (Denis \& Schiffermüller, 1775)

H. nimbella (Duponchel, 1837)

Phycitodes binaevella (Hübner, 1813)

Plodia interpunctella (Hübner, 1813)

Ephestia elutella (Hübner, 1796)

Anerastia lotella (Hübner, 1813)

Ematheudes punctella (Treitschke, 1833)

\section{Crambidae}

Scoparia subfusca Haworth, 1811

S. pyralella (Denis \& Schiffermüller, 1775)

S. basistrigalis Knaggs, 1866

Gesneria centuriella (Denis \& Schiffermüller, 1775)

Dipleurina lacustrata (Panzer, 1804)

Eudonia mercurella (Linnaeus, 1758)

Witlesia pallida (Curtis, 1827)

Heliothela wulfeniana (Scopoli, 1763)

Eucromius bellus (Hübner, 1796)

Chilo phragmitella (Hübner, 1805)

Fridlanderia cicatricella (Hübner, 1824)

Calatomorpha paludella (Hübner, 1824)

C. aureliellus (Fischer v. Röslerstamm, 1841)

Chrysoteuchia culmella (Linnaeus, 1758)

Crambus pascuellus (Linnaeus, 1758)

C. silvellus (Hübner, 1813)

C. uliginosellus Zeller, 1850

C. pratellus (Linnaeus, 1758)

C. lathoniellus (Zincken, 1817)

C. perlellus (Scopoli, 1763)

Agriphila tristella (Denis \& Schiffermüller, 1775)

A. inquinatella (Denis \& Schiffermüller, 1775)

A. selasella (Hübner, 1813)

A. straminella (Denis \& Schiffermüller, 1775)

A. tersella hungarica (Schmidt, 1909) [21.]

A. tollia pelsonius Fazekas, 1985 [22.]*

Catoptria pinella (Linnaeus, 1758)

C. falsella (Denis \& Schiffermüller, 1775)
C. verella (Zincken, 1817)

Metacrambus carectellus (Zeller, 1847)

Xanthocoambus lucellus (Hemich-Schäffer, 1848) [23.]*

Chrysocrambus linetella (Fabricius, 1781)

C. craterella (Scopoli, 1763)

Thisanotia chrysonuchella (Scopoli, 1763)

Pediasia luteella (Denis \& Schiffermüller, 1775)

$P$. contaminella (Hübner, 1796)

P. aridella (Thunberg, 1788)

Platytes cerusella (Denis \& Schiffermüller, 1775)

$P$. alpinella (Hübner, 1813)

Talis quercella (Denis \& Schiffermüller, 1775)

Schoenobius gigantella (Denis \& Schiffermüller, 1775)

Donacaula forficella (Thunberg, 1794)

D. mucronella (Denis \& Schiffermüller, 1775)

Scirpophaga praelata (Scopoli, 1763)

Elophila nymphaeata (Linnaeus, 1758)

Acentria ephemerella (Denis Schiffermüller, 1775)

Cataclysta lemnata (Linnaeus, 1758)

Parapoynx startitata (Linnaeus, 1758)

Nymphula stagnata (Donovan, 1806)

Aporodes floralis (Hübner, 1809)

Cynaeda dentalis (Denis \& Schiffermüller, 1775)

Epascetria pustulalis (Hübner, 1823)

Altralata albofascialis (Treitschke, 1829)

Titanio normalis (Hübner, 1796)

Evergestis frumentalis (Linnaeus, 1761)

E. forficalis (Linnaeus, 17589)

E. extimalis (Scopoli, 1763)

E. limbata (Linnaeus, 1767)

E. pallidata (Hufnagel, 1767)

E. aenealis (Denis \& Schiffermüller, 1775)

Udea ferrugalis (Hübner, 1796)

$U$. accolalis (Zeller, 1867)

Paracorsia repandalis (Denis \& Schiffermüller, 1775)

Obsibotys fuscalis (Denis \& Schiffermüller, 1775)

Margaritia sticticalis (Linnaeus, 1761)

Ecpyrrhorrhoe rubiginalis (Hübner, 1796)

Pyrausta cingulata (Linnaeus, 1758)

Pyrausta rectefascialis Toll, 1936

P. sanguinalis (Linnaeus, 1767)

P. despicata (Scopoli, 1763)

P. aurata (Scopoli, 1763)

P. purpuralis (Linnaeus, 1758)

P. ostrinalis (Hübner, 1796)

P. falcatalis Guenée, 1854

P. nigra (Scopoli, 1763)

Uresiphita gilvata (Fabricius, 1794)

Nascia cilialis simplicalis Caradja, 1916

Sitochrva palealis (Denis \& Schiffermüller, 1775)

S. verticalis (Linnaeus, 1758)

Perinephela lancealis (Denis \& Schiffermüller, 1775) 
Phlyctaenia coronata (Hufnagel, 1767)

Ph. stachydalis (Germar, 1821)

Ph. perlucidalis (Hübner, 1809)

Mutuuraia terrealis (Treitschke, I 829)

Sclerocona acutella (Eversmann, 1842)

Psammotis pulveralis (Hübner, 1796)

Ostrinia palustralis (Hübner, 1796) [24.]*

O. nubilalis (Hübner, 1796)

Ebulea crocealis (Hübner, 1796)

Anania verbascalis (Denis \& Schiffermüller, 1775)

Eurrhypara hortulata (Linnaeus, 1758)
Paratalanta pandalis (Hübner, 1825)

P. hyalinalis (Hübner, 1796)

Pleuroptya ruralis (Scopoli, 1763)

Mecyna lutealis (Duponchel, 1833)

Agrotera nemoralis (Scopoli, 1763)

Diasemia reticularis (Linnaeus, 1761)

Dolicharthria punctalis (Denis \& Schiffermüller, 1775)

Metasia ophialis (Treitschke, 1829)

Nomophila noctuella (Denis \& Schiffermüller, 1775)

\section{Jegyzetek}

\section{Tineidae}

[1.] Nemapogon clematella (Fabricius, 1781), syn.: arcella Fabricius, 1777: RAZOWSKI - KARSHOLT (1996) az európai fajlistában Magyarországról nem közölték. GOZMÁNY (1956a) már korábban kimutta Ócsáról és a Mecsekból, majd késóbb a Bükkból is elókerült. Somogy megyében Kaposváron gyújtötték (leg. Nattán).

\section{Psychidae}

[2.] Apterona crenulella (Bruand, 1853): A nôstények szúznemzéssel szaporodnak. A fajkomplex taxonómiája és biológiája még nem kellóképpen tisztázott. Somogyi areája bizonytalan alapokon nyugszik.

\section{Plutellidae}

[3.] Rhigognostis kovácsi (Gozmány, 1952): Pannoniai endemikus faj, amelyet a Kis-Balaton területéról írtak le. Késóbb Középrigócon is megtalálták. Magyarország határain kívúl másutt még nem gyújiötték. A populációk mérete, veszélyeztetettsége nem ismert

\section{Oecophoridae}

[4.] Pleurota brevispinella (Zeller, 1847): Európában csupán Krétáról, Sziciliából és Magyarországról ismert faj. Somogy megyében csak Kaposváron gyújtötték.

\section{Coleophoridae}

[5.] Coleophora otidipennella (Hübner, 1817), syn.: murinipennella Duponchel, 1844 : RAZOWSKI - KARSHOLT (1996) az európai fajlistában Magyarországról nem közölték. GOZMÁNY (1955) szerint a hazai adatok egy része téves határozáson alapul (pl. Vörs), ugyanakkor budapesti elófordulását hitelesnek tartja. Szabóky (1983 a) szerint Kaposváron gyúitötték: I951.V.30. A somogyi adatot csak genitália vizsgálatokkal lehet igazolni, amelyet eddig nem végeztek el.

\section{Momphidae}

[6.] Mompha divisiella Herrich-Schäffer, 1854, syn.: decorella Stephens, 1834 nom. praeocc.: Földrajzi elterjedése: Európa, a Kaukázus vidéke, Türkmenisz- 
tán, Kazahsztán. RAzOWSKI - KARSHOLT (1996) az európai fajlistában Magyarországról nem közölték. GozMÁNY (1958) szerint, hazánkban is előfordul: Tokod és Kaposvár. A divisiellat gyakran felcserélik a hozzá morfológiailag igen közelálló Mompha bradleyi Riedl, 1965 fajjal. A fajpár egzakt identifikálása csak genitália vizsgálattal végezhetô el. A fenti anomáliákra egy késóbbi munkámban vissza fogok térni.

\section{Cosmopterigidae}

[7.] Pyroderces klimeschi Rebel, 1938: Magyarországról leírt faj (locus typicus: Kis-Balaton). Földrajzi elterjedése: Lengyelország, Szlovákai, Ausztria, Magyarország, Románia és Olaszország. Somogy megyei lelôhelyei: Kis-Balaton, Fonyód. Somogyon kívúl hazánkból csak a Kiskunsági Nemzeti Parkból és Pákozdról (Kanca-hegy) ismert. Feltehetôleg veszélyeztetett, védelemre érdemes faj.

\section{Gelechiidae}

[8.] Monochroa divisiella (Douglas, 1850), syn.: lepidolampra Gozmány, I952: A D-Dunántúlon csak Somogy megye láprétjeiről ismert: Darány, Fonyód, KisBalaton. Megtalálták az alföldi mocsárvidékeken is. Európai elterjedése: Közép-Európában $(\mathrm{D}, \mathrm{CH}, \mathrm{H})$ és Litvániában fragmentális. Dániában, Hollandiában, a Brit-szigeteken is csupán izolált populációi ismertek.

[9.] Scrobipalpa hungariae (Staudinger, 1871): A Kárpát-medence endemikus faja. Csak Magyarországon és Burgenlandban ismert. Somogy megyei lelóhelye: Kaposvár.

[10.] Sophronia ascalis (Gozmány, 1951): A Kárpát-medence endemikus faja, amely Magyarországról, Burgenlandból és D-Szlovákiából ismert. Locus typicus: Kaposvár. A típuslelóhelyen kívúl Fonyódon is gyúitötték.

[11.] Syncopacma albipalella (Herrich-Schäffer, 1854): RAZOWSKI - KARSHOLT (1996) az európai fajlistában Magyarországról nem közölték. GOZMÁNY (1958) korábban megállapította, hogy a fajnak „minden Németországon kívüli adata kétes“. Az újabb kutatások szerint (vö. RAzOwSKI - KARSHOLT, 1996) elókerült a Brit-szigetekrôl, több közép-európai országból, Ny- és D-Európából is. Megerôsítésre szoruló adatok alapján állítólag Kaposváron is gyújtötték (Petrich in litt.).

\section{Zygaenidae}

[12.] Zygaena trifolii (Esper, 1783): A politipikus, atlantomediterrán faunaelem magyarországi előfordulását az újabb kutatások nem erôsítették meg (FAZEKAS, 1998, 2000b). A GOZMÁNY (1963) által identifikált kaposvári példány eredetét a szerző nem tartotta „hitelesnek“. A faj somogyi faunából való törléséhez megfelelő bizonyíték áll rendelkezésünkre.

\section{Brachodidae}

[13.] Brachodes nana (Treitschke, 1834): RAzowsKI - Karsholt (1996) az európai fajlistában Magyarországról nem említették. Hazánkban Bugacon, Barcson, Nyirádon és Tatán gyújtötték (Petrich in litt.). Földrajzi elterjedése: a volt Szovjetúnió európai területének déli része, a Balkán-félsziget, Törökország és az Ibériai-félsziget.

\section{Sesiidae}

[14.] Synanthedon mesiaeformis (Herrich-Schäffer, 1846): Magyarországon csak Somogyból ismert: Kaposvár, Darány. Hazánkban először PAZsıCzKY 
(1941) fedezte fel. Az imágókat (4 ex.) 1934-ben ill. 1938-ban gyúijtötték. Azóta csupán egy hernyóból kinevelt példány került elô a '80-as években (LASTUVKA, 1990). Hazánkban feltehetóleg veszélyeztetett, védelemre érdemes expanzív, pontomediterrán faj.

\section{Cossidae}

[15.] Lamellocossus terebra (Denis \& Schiffermüller, 1775): Első hazai példányát Kaposváron gyújtötték. Magyarországon izolált populációi az Alpokalján, a D-Dunántúlon (Somogy, Mecsek), az Alföldön (Dráva-sík, Beregi-sík) és az Északi-középhegységben találhatók (Zempléni-hegység). Védett és veszélyeztetett faj, amelynek biológiáját alig ismerjük. Eszmei értéke: $10.000 \mathrm{Ft}$.

\section{Tortricidae}

[16.] Acleris kochiella (Goeze, 1783), syn.: boscana Fabricius, 1794: A faj Európában sokfelé elöfordul. RAZOWSKI - KARSHOLT (1996) az európai fajlistában Magyarországról nem említik. SZABÓKY (1983 ab) szerint Somogyban Kaposváron és Darányban gyưjtötték.

[17.] Metendothenia atropunctana (Zetterstedt, 1839): Az Európában széles körben elterjedt fajt nem tekintik a magyar fauna tagjának (vö. RAzOWSKI KARSHOLT, 1996). Somogyban a barcsi borókásban gyújtötték (SZABÓKY, 1983b). A D-Dunántúlon a Mecsekból is ismert (FAZEKAS, 1995c).

[18.] Pristerognatha fuligana (Denis \& Schiffermüller, 1775): Az alpi-kárpáti térségben csupán Svájcból, Ausztriából és Romániából jelezték előfordulását (RAZOWSKI - KARSHOLT, 1996). SZABÓKY (1983a) „Endothenia fuligana Haw.“ néven Fonyód lelóhelyról közölte.

[19.] Ancylis diminutana (Haworth, 1811): Az európai fajlistában magyarországi adata nem szerepel (RAzOWSKI - KARSHOLT, 1996), s Közép-Európából is csak Svájcból jelezték. A korábbi hazai faunalisták szerint (GOZMÁNY, 1952) a faj tagja a magyar faunának. SZABÓKY (1983a) közleményében (Nattángyújtemény) kaposvári példányokról számolt be.

\section{Pterophoridae}

[20.] Merrifieldia malacodactyla transdanubinus (FAZEKAS, 1986): A Kárpát-medencében endemikus alfajt Somogy megyéből írtam le (locus typicus: Kaposvár). A malacodactyla egy tipikusan „széthasadt faj“ (splittende Art), amelynél a parapatrikusság egyértelmúen bizonyítható. Az egymással nem érintkező allopatrikus populációkban fóleg a hím genitáliák divergenciája szembetúnố (vö. FAZEKAS, 2000a).

\section{Crambidae}

[21.] Agriphila tersella hungarica (Schmidt, 1909): A hungaricat eredetileg önálló fajként írták le (locus typicus: Mezőberény), és sokáig kárpát-medencei endemizmusnak tekintették (SZZENT-IVÁNY - UHRIK-MÉSZÁrOS, 1942). Egyes taxonómusok még ma is különálló fajnak tartják. Valójában a politipikus $A$. tersella (Lederer, 1855) olyan „változatáról“, rasszáról van szó, amelynek alfaji státusza egyértelmúen nem bizonyított (FAZEKAS, 1984).

[22.] Agriphila tolli pelsonius Fazekas, 1985: A Kárpát-medence endemikus alfaja. Az Agriphila geniculea Haw. - A. tolli Bl. fajpár magyarországi taxonómiai, ökofaunisztikai és biogeográfiai anomáliáit éppen a Nattán-gyújtemény Crambinae anyagának reviziója hozta felszínre (F^ZEKAS, 1986). A palearktikus kutatások eredményeit a közelmúltban közöltem (FAZEKAS, 1991; 1995b). 
[23.] Xanthocrambus lucellus (Herrich-Schäffer, 1848): A palearktikumban Japántól Európáig előforduló, diszjunkt areájú fajt Magyarországról írták le (locus typicus: nincs pontosítva, a típus elveszett). Preimaginális állapota ma is ismeretlen. Hazánkból sokáig csak az alföldi élôhelyeken gyúitötték. Újabban a kollin-montán területeken is megtalálták (FAZEKAs, 1996). Somogyból csak régi gyújtésú példányok ismertek Kaposvárról és Kiskorpádról (FAZEKAS, 1986; 1989).

[24.] Ostrinia palustralis (Hübner, 1796): Elsố somogyi példányát Vörsön gyúitötték (leg. Schmidt) a múlt század elején. Azóta csak Balatonföldvárról és Fonyódról került elô. A Bánátból leírt taxon a nedves, mocsaras élóhelyek jellemző faja. A hazai populációk mérete, veszélyeztetettsége nem ismert. Védett: eszmei értéke $2000 \mathrm{Ft}$.

\section{Összefoglalás}

Somogy megyében a hazai microlepidoptera 46,83 \%-át, az európai fauna 17,48 \%-át gyúitötték. A magyarországi ismert microlepidoptera családok közül csak a 2-2 fajt képviselô Pterolonchidaek és a Carposinidaek fajait nem találták meg Somogy megyében. Európában jelenleg 66, Magyarországon 59 microlepidoptera család ismeretes.

A rendelkezésünkre álló irodalmi és gyưjiteményi adatok alapján Somogy megyéból eddig 971 microlepidoptera fajt lehet kimutatni, amely a magyar fauna $46 \%$ a. A relatíve magas fajszám ellenére a megye microlepidoptera kutatottságát csak részben tekinthetjük megfelelönek. Az eddigi gyújtések döntően Kaposvár környékére és a barcsi tájvédelmi körzetre koncentrálódtak, más területeken csupán alkal-

1. táblázat: A Somogy megyében előforduló microlepidoptera családok kvalitatív és kvantitatív összehasonlítása a magyarországi és az európai adatokkal.

Rövidítések: $\mathrm{SO}=$ Somogy megye, $\mathrm{HU}=$ Magyarország, $\mathrm{EU}=$ Európa

\begin{tabular}{|l|c|c|c|}
\hline \multirow{2}{*}{ Család } & \multicolumn{3}{c|}{ Fajszám } \\
\cline { 2 - 4 } & SO & HU & EU \\
\hline 1. Micropterigidae & 4 & 7 & 41 \\
\hline 2. Eriocraniidae & 2 & 3 & 9 \\
\hline 3. Hepialidae & 2 & 6 & 16 \\
\hline 4. Nepticulidae & 2 & 108 & 210 \\
\hline 5. Opostegidae & 3 & 4 & 6 \\
\hline 6. Heliozidae & 2 & 4 & 8 \\
\hline 7. Adelidae & 16 & 30 & 52 \\
\hline 8. Prodoxidae & 2 & 6 & 20 \\
\hline 9. Incurvariidae & 4 & 6 & 12 \\
\hline 10. Tischeriidae & 6 & 8 & 9 \\
\hline 11. Tineidae & 25 & 54 & 222 \\
\hline 12. Lypusidae & 1 & 1 & 1 \\
\hline 13. Psychidae & 22 & 42 & 213 \\
\hline 14. Roeslerstammidae & 2 & 2 & 2 \\
\hline 15. Douglasiidae & 1 & 4 & 13 \\
\hline 16. Bucculatricidae & 9 & 19 & 47 \\
\hline 17. Gracillariidae & 59 & 110 & 215 \\
\hline 18. Yponomeutidae & 26 & 39 & 106 \\
\hline
\end{tabular}




\section{1. táblázat folytatása}

\begin{tabular}{|c|c|c|c|}
\hline \multirow{2}{*}{ Család } & \multicolumn{3}{|c|}{ Fajszám } \\
\hline & SO & HU & EU \\
\hline 19. Ypsolophidae & 9 & 18 & 42 \\
\hline 20. Plutellidae & 3 & 15 & 20 \\
\hline 21. Acrolepiidae & 4 & 7 & 21 \\
\hline 22. Glyphipterigidae & 4 & 8 & 18 \\
\hline 23. Heliodinidae & 1 & 1 & 1 \\
\hline 24. Bedellidae & 2 & 2 & 2 \\
\hline 25. Lyonetiidae & 3 & 13 & 27 \\
\hline 26. Ethmiidae & 8 & 9 & 27 \\
\hline 27. Depressariidae & 29 & 60 & 152 \\
\hline 28. Elachistidae & 20 & 73 & 212 \\
\hline 29. Agonexidae & 4 & 10 & 15 \\
\hline 30. Deuterogoniidae & 1 & 1 & 1 \\
\hline 31. Scythrididae & 4 & 20 & $15 \mathrm{I}$ \\
\hline 32. Chimabachidae & 3 & 3 & 3 \\
\hline 33. Oecophoridae & 30 & 40 & 126 \\
\hline 34. Lecithoceridae & 1 & 2 & 11 \\
\hline 35. Batracheridae & 2 & 3 & 3 \\
\hline 36. Coleophoridae & 53 & $\mathrm{I} 68$ & 429 \\
\hline 37. Momphidae & 8 & 13 & 18 \\
\hline 38. Blastobasidae & 3 & 4 & I9 \\
\hline 39. Autostichidae & 4 & 9 & 94 \\
\hline 40. Amphibastidae & 4 & 8 & 26 \\
\hline 41. Cosmopterigidae & 7 & 22 & 64 \\
\hline 42. Gelechiidae & 105 & 235 & 617 \\
\hline 43. Limacodidae & 2 & 2 & 4 \\
\hline 44. Zygaenidae & 18 & 24 & 63 \\
\hline 45. Brachodidae & 1 & 2 & 11 \\
\hline 46. Sesiidae & 24 & 35 & 111 \\
\hline 47. Cossidae & 5 & 7 & 19 \\
\hline 48. Tortricidae & 205 & 427 & 925 \\
\hline 49. Choreutidae & 4 & 10 & 14 \\
\hline 50. Urodidae & 1 & 1 & 1 \\
\hline 51. Schreckensteiniidae & 1 & 1 & 1 \\
\hline 52. Epermeniidae & 5 & 11 & $2 \mathrm{I}$ \\
\hline 53. Alucitidae & 2 & 6 & 16 \\
\hline 54. Pterophoridae & 23 & 62 & 184 \\
\hline 55. Thyrididae & 1 & 1 & 1 \\
\hline 56. Pyralidae & 79 & 141 & 450 \\
\hline 57. Crambidae & 100 & 173 & 401 \\
\hline Fajszám összesen: & 971 & 2071 & 5547 \\
\hline
\end{tabular}

mi és szórványos gyújtések voltak. Az itt összeállított faunalista Somogy megye microlepidoptera faunájának olyan elsô alapvetése, amely a következó évek taxonómiai, ökofaunisztikai és biogeográfiai vizsgálatai során jelentősen módosulhat. Új eredmények nemcsak a megye egész területére kiterjesztett tervszerú gyưjtésektól várhatók, hanem több faj illetve fajcsoport taxonómiai reviziójától is. Az elóbbiek alapján a most közreadott somogy megyei microlepidoptera fajlistát úgy kell tekintenünk, hogy megteremtettük azt az alapot, amely lehetőséget ad a most elkezdődó átfogó kutatásokhoz. 
Somogyban 6 olyan faj és alfaj él, amelyet jelenlegi biogeográfiai ismereteink alapján kárpát-medencei endemizmusnak tekinthetünk. Ezek a következók: Rhigognostis kovácsi (Gozmány, 1952), Plutellidae; Scrobipalpa hungariae (Staudinger, 1871), Gelechiidae; Sophronia ascalis (Gozmány, 1951), Gelechiidae; Merrifieldia malacodactyla transdanubinus (Fazekas, 1986), Pterophoridae; Agriphila tersella hungarica (Schmidt, 1909), Crambidae; Agriphila tolli pelsonius Fazekas, 1985, Crambidae.

Több faj és alfaj típuslelóhelye (locus typicus) Somogy megyében található. Ilyen taxonok az alábbiak: Rhigognostis kovácsi (Gozmány, 1951), Plutellidae; Pyroderces klimeschi Rebel, 1938, Cosmopterigidae; Sophronia ascalis (Gozmány, 1951), Gelechiidae; Merrifieldia malacodactyla transdanubinus (Fazekas, 1986), Pterophoridae. A típuslelóhelyek megőrzése, a populációk védelme palearktikus jelentôségú, $s$ a regionális természetvédelem fontos feladata.

\section{Irodalom}

Abafi-Aigner, L., PÁvel, J., - Uhruk, N., 1896: Lepidoptera. In: Fauna Regni Hungariae III. Artropoda - Budapest, $82 \mathrm{pp}$.

Arenberger, E., 1995: Pterophoridae, 1 Teil: Pterophorinae, Ochyroticinae und Agdistinae In: Amsel H.G., Reisser H. \& Gregor F.: Microlepidoptera Palaearctica, 9:I- XXV, 258 pp, Taf. 1-153, Karlsruhe.

BAlogh, I., 1939: Neue fanunistische angeben aus der Familie Tortricidae - Fragmenta Faun. Hung., 2(2): 21.

Efetov, K.A., \& TARmann, G. M., 1999: Forester Moths. The genera Theresimima Strand, 1917, Rhagades Wallengren, 1863, Jordanita Verity, 1946, and Adscita Retzius, 1783 - Apollo Books, Stenstrup, 192 pp, Figs. 1-415.

FAZEKAS, I., 1980: Bausteine zur Kenntnis der Zygaenidae-Fauna Ungarns I. Die Grünzygaenen des SW-Transdanubiens - J. Pannonius Múz. Évk., 24: 45-62.

FAZEKAS, I., 1981: Bausteine zur Kenntnis der Zygaeniden-Fauna Ungarns III. Die Zygaeniden des Landschaftschutzgebietes „Barcs'er“ Wachholderheide - Dunántúli Dolg. Term.-tud. Sor., 2: 81-88.

FAZEKAS, I., 1984: Angaben zur Pyraloidea-Fauna des Bakony-Gebirges I. Crambus nemorella Hbn. und Agriphila tersella tersella Led. - Folia Mus. Hist.-nat. Bakonyiensis, 3: 181-184.

FAZEKAS, I., 1986: $\Lambda$ Nattán-gyújtemény Crambinae és Schoenobiinae fajainak reviziója - Folia Comloensis, 2: 129-142., 5 tábla.

FAzekas, 1., 1988: Adatok Magyarország Pterophoridae faunáának ismeretéhez, 4. Dél-Dunántúl Pterophoridae fajai és elterjedésük - Állattani Közl., 74: 17-27.

Fızekas, I., 1989: A Dél-Dunántúl Crambinae fajai és elterjedésük - Állattani Közl., 75: 43-48.

FAzEKAS, I., 1991: Agriphila tolli beieri Bleszynski, 1955 status novus - Ann. Naturhist. Mus. Wien, 92(B): 113-119.

FAZEKAS, I., 1992a: Systematisch-faunistisches Verzeichnis der Pterophoriden Ungarns - Nachr. entomol. Ver. Apollo, N.F. I3(2a): 191-200.

FAZEKAS, I., 1992b: A Stenoptilia annadactyla Sutter, 1988 és a S. gratiolae Gibeaux et Nel, 1990 előfordulása Magyarországon - Állattani Közl., 78: 29-31.

FazeKaS, I., 1994a: Systematisch-faunistisches Verzeichnis der Pterophoriden Ungarns. Nr. 2. Erg(nzungen - Nachr. entomol. Ver. Apollo, N.F. 15(1/2): 25-27.

FAzeKAS, I., 1994b: Az Agriphila geniculea Haw. és az A. tolli Bl. magyarországi elterjedése - Folia Hist. Nat. Mus. Matr., 19: 97-105.

FNZEKAS, I., 1994c: A magyarországi makrorégiók Cochylini faunája I. A Dunántúli-dombság - Állattani Közl., 80: 35-56.

FAzeKAS, I., 1995a: Beitrage zur Pterophoriden-Fauna des Balkans und des Karpatenbeckens Nachr. entomol. Ver. Apollo, N.F. 16(1): 99-113. 
FAZEKAS, I., 1995b: Die geographische Verbreitung der Art Agriphila tolli Bl. in Europa - NachrBl. bayer. Ent., 44: 17-24.

FAZEKAS, 1., 1995c: A Mecsekvidék és a Völgység sodrómolylepke faunája - Folia Comloensis, 6: 5-33.

FAzEKAS, I., 1995e: Systematic Catalogue of the Crambinae of Hungary - Storkia, Den Haag, 4: 1-9.

FAZEKAS, I., 1995d: Systematisches und synonymisches Verzeichnis der Cochylini Ungarns Nachr. entomol. Ver. $\Lambda$ pollo, N.F. 16(1): 29-46.

FAzekAS, I., 1996: Systematic Catalogue of the Pyraloidea, Pterophoroidea and Zygaenoidea of Hungary - Folia Comloensis, suppl., 34 pp.

FAZEKAS, I., 1998: An annotated, systematic and distributional list of the Zygaenidac of Hungary - NachrBl. bayer. Ent., 47(1/2):2-17.

Fazekas, I., 2000a: Pterophoridae Hungariae, Fasciculus I. Pterophorinae-Agdistinae - Folia Comloensis, 8: 3-102.

FAZEKAS, I., 2000b: Microlepidoptera Pannoniae meridionalis I. A Dél-Dunántúl Zygaeninae fajai és elterjedésük - Folia Comloensis, 9: 71-86.

GAEDIKE, R., 1966: Beitrag zur Epermeniidae-Fauna Ungarns - Folia ent. hung., 19:479-490.

Giels, C., 1996: Pterophoridae. In: Huemer P., Karsholt O. \& Lyneborg L.: Microlepidoptera of Europe, Vol. 1 - Apollo Books, Stenstrup, 222 pp.

GozmÁnY, L., 1955: Molylepkék III. Microlepidoptera III. - Fauna Hung., XVI., 4: 64 pp.

GoZMÁNY, L., 1956a: Molylepkék II. Microlepidoptera II. - Fauna Hung., XVI., 3: 136 pp.

GoZmÁNY, L., 1956b: The Microlepidoptera Coenoses of the Kisbalaton - Acta Zool. Ac. Sci. Hung., 7: 415-418.

GoZmÁnY, L., 1958: Molylepkék IV. Microlepidoptera IV. - Fauna Hung., XVI., 5: 295 pp.

GozmÁNy, L., 1963: Molylepkék VI. Microlepidoptera I. - Fauna Hung., XVI., 7: 289 pp.

GozmÁnY, L., SzŐ́Cs, J., 1965: Molylepkék I. Microlepidoptera I. - Fauna Hung., XVI., 2: 214 pp.

GoZMÁNY, L., 1971: Megemlékezés Nattán Miklósról (1910-1970) - Folia ent. hung., 24: 279-280.

LASTuvKর, Z., 1990: Die Glasflügler Ungarns-faunistik und bionomie - J. Pannonius Mus. Évk., 34: 39-46.

Huemer, P. \& Karsholt, O., I999: Gelechiidae I. Gelechiinae: Teleiodini, Gelechiini. In: Huemer P., Karsholt O. \& Lyneborg L.: Microlepidoptera of Europe. Vol. 3 -Apollo Books, Stenstrup, 356 pp.

Nauman, C. M., Tarmann, G.M., - Tremewan W.G., 1999: The Western Palaearctic Zygaenidae - Apollo Books, Stenstrup, 304 pp.

PAZsiCZKY, S., 1941: Synanthedon mesiaeformis HS. elófordulása Somogyban - Folia ent. hung., 6:36-37.

PAZSICZKY, S., 1947: Három kaposvári lepkész emlékezete - Folia ent. hung., 2(1): 1-3.

Szabóky, Cs., 1983a: A Dél-Dunántúl molylepkéi I. Nattán Miklós molylepke-gyúijteménye - J. Pannonius Múz. Évk., 27: 15-35.

SzABÓKY, Cs., 1983b: A barcsi borókás molylepkefaunája I. - Dunántúli Dolg. Term.-tud. Sor., 3:47-54. SZABÓKY, CS., 1985: A barcsi borókás molylepkefaunája II. - Dunántúli Dolg. Term.-tud. Sor., 5: 234-236. Szent-Ivány, J., Uhrık-MÉszáros, T., 1942: Die Verbreitung der Pyralididen im Karpatenbecken Ann. Hist.-nat. Hung., Pars zool., 35: 105-196.

SzILÁDY, Z., 1903: A magyar állattani irodalom ismertetése. III. 1891-1900 - Kir. Magyar Term.tud. Társulat, Budapest, 502 pp.

Szöcs, J., 1973: Újabb molylepkék a magyar faunában - Folia ent. hung., 26: 155-164. 


\section{Microlepidoptera fauna of Somogy county (SW-Hungary) (Microlepidoptera)}

\section{IMRE FAZEKAS}

Until now no general work has been published on the Microlepidoptera fauna of Somogy county, $6082 \mathrm{~km}^{2}$ on the south-west part that covers of Hungary. The author compiled the checklist of the county's Microlepidoptera species on the basis of literary and collected data in honour of 1000 year anniversary (millennium) of fundation Hungary. Recent study is the first part of an a overall comprehensive taxonomical, faunistical and biogeographical cataloguing of the EU-region. Now the author is publishing the second part of the serial titled „Microlepidoptera Pannoniae meridionalis” (see FAZEKAS, 2000b).

There is a strong influence of west Balkan and submediterranean flora and fauna in the examined geographical area. There are mostly Sessile oak-Turkey oak forests and other oakwoods on acidifying soils and Illyrian oak-hornbeam forests in this area. But loess-steppes and sand-steppes vegetation assotiations can be found as well.

97 I Microlepidoptera species can be found in Somogy county, representing $46 \%$ of the Hungarian fauna. Although a high number of species has been recorded, we hardly know the county's fauna. More serious research has been carried out only around Kaposvár and in some nature conservation areas. We have no details from the most parts of the county.

There are more points of interest from systematic aspects. The locus typicus of the following species can be found here: Rhigognostis kovácsi (Gozmány, 1951), Plutellidae; Pyroderces klimeschi Rebel, 1938, Cosmopterigidae; Sophronia ascalis (Gozmány, 1951), Gelechiidae; Merrifieldia malacodactyla transdanubinus (Fazekas, 1986), Pterophoridae.

The endemic species and subspecies in the Carpathian Basin are important from biogeographical and nature conservation point of view: Rhigognostis kovácsi (Gozmány, 1952), Plutellidae; Scrobipalpa hungariae (Staudinger, 1871), Gelechiidae; Sophronia ascalis (Gozmány, 1951), Gelechiidae; Merrifieldia malacodactyla transdanubinus (Fazekas, 1986), Pterophoridae: Agriphila tersella hungarica (Schmidt, 1909), Crambidae; Agriphila tolli pelsonius Fazekas, 1985, Crambidae.

According to the Hungarian nature conservation law there are four taxon under protection: Adscita geryon (Hübner, 1813), Zygaena laeta (Hübner, 1790), Zygaenidae; Lamellocossus terebra (Denis \& Schiffermüller, 1775), Cossidae; Ostrinia palustralis (Hübner, 1796), Crambidae.

Author's address:

Imre FAZEKAS

Natural Historical Collection at Komló

H-7300 Komló

Városház tér l.

HUNGARY

E-mail: fazekas.i@dpg.hu 